\title{
Temporal and spatial variability of photosynthetic parameters and community respiration in Long Island Sound
}

\author{
Nicole L. Goebel ${ }^{1,2, *}$, James N. Kremer ${ }^{1}$ \\ ${ }^{1}$ Department of Marine Sciences, University of Connecticut at Avery Point, Groton, Connecticut 06340, USA \\ ${ }^{2}$ Present address: Ocean Sciences Department, University of California, Santa Cruz, California 95062, USA
}

\begin{abstract}
Photosynthetic parameters and community respiration were measured throughout 3 seasons at 8 stations in central and western Long Island Sound during 2002 and 2003. Light-dark bottle oxygen change was measured in a photosynthesis-irradiance $(P-I)$ series for water from the mixed layer, and respiration was measured for surface, pycnocline, and near bottom water. $P-I$ curves were fitted numerically to calculate biomass-specific rates of maximum photosynthesis at light saturation $\left(P_{\mathrm{m}}^{B}\right)$, photosynthetic efficiency at low irradiance $\left(\alpha^{B}\right)$ and plankton community respiration $\left(R_{\mathrm{c}}\right)$. The temporal and spatial variability of these fitted parameters, the derived parameter $I_{\mathrm{k}}$, and the concentration of phytoplankton pigments were described in relation to each other and to environmental factors. Concentrations of chlorophyll (chl) and phaeopigments (phaeo), and $R_{\mathrm{c}}$ reached maxima in summer and significantly decreased seaward along the length of the Sound. Photosynthetic parameters also reached maxima in summer, however there was no significant spatial variability. In surface waters, the average $( \pm \mathrm{SD})$ of $P_{\mathrm{m}}^{B}\left(1.3 \pm 0.4 \mathrm{mmol} \mathrm{O}_{2}\left[\mathrm{mg} \mathrm{chl}^{-1} \mathrm{~h}^{-1}\right)\right.$ demonstrated the lowest variability, compared to chl $\left(6.9 \pm 4.9 \mathrm{mg} \mathrm{m}^{-3}\right)$, phaeo $\left(3.5 \pm 2.5 \mathrm{mg} \mathrm{m}^{-3}\right), \alpha^{B}\left(10.9 \pm 5.4 \mu \mathrm{mol} \mathrm{O}{ }_{2}\left[\mathrm{mg} \mathrm{chl}^{-1} \mathrm{~h}^{-1}\right.\right.$ $\left.\left[\mu \mathrm{E} \mathrm{m}^{-2} \mathrm{~s}^{-1}\right]^{-1}\right), I_{\mathrm{k}}\left(132.6 \pm 71.9 \mu \mathrm{E} \mathrm{m}^{-2} \mathrm{~s}^{-1}\right)$, and $R_{\mathrm{c}}\left(1.4 \pm 0.9 \mathrm{mmol} \mathrm{O}_{2} \mathrm{~m}^{-3} \mathrm{~h}^{-1}\right)$. Chl and $P_{\mathrm{m}}^{B}$ both varied with total daily insolation and with average irradiance of the photic zone, while $P_{\mathrm{m}}^{B}$ was also correlated with temperature. Although $P_{\mathrm{m}}^{B}$ and chl increased during summer, their peaks did not occur simultaneously. Temporal trends in $\alpha^{B}$ were less clear-cut than for $P_{\mathrm{m}}^{B}$ and chl, but $\alpha^{B}$ was correlated with light properties of the water column. Plankton community respiration was high in surface waters and decreased with depth. Based on the relationship between $R_{\mathrm{c}}$ and chl, algal-related rates of respiration $\left(R_{\mathrm{a}}\right)$ were estimated at $\sim 50 \%$ of total plankton community respiration. Our results do not support the common method of estimating algal respiration based on $P_{\mathrm{m}}^{B}$.
\end{abstract}

KEY WORDS: Productivity - Primary production - Respiration ' Oxygen ' Chlorophyll · Phytoplankton community · Long Island Sound

Resale or republication not permitted without written consent of the publisher

\section{INTRODUCTION}

Autochthonous phytoplankton production has been targeted as the key contributor to hypoxia in eutrophic systems such as Long Island Sound (LIS), yet has not been well characterized in this system. Although limited investigations of the mechanisms that control hypoxia in LIS have recognized this underlying ecological process (Welsh \& Eller 1991, Anderson \& Taylor 2001), the scope of such studies did not allow for the characterization of rates in space and time, the estima- tion of integrated rates for the whole Sound, or formulation of a model of primary production in LIS. As a first step for such calculations, this study reports measurements of temporal and spatial patterns in the photosynthetic characteristics and phytoplankton biomass in relation to each other and to environmental factors.

Photosynthetic parameters are derived from measured variations in the phytoplankton response to light (a photosynthesis-irradiance relationship, or $P-I$ curve; see e.g. Fig. 4). Typically, a linear response at low light levels approaches an asymptotic maximum rate at high 
light levels (Platt \& Jassby 1976, Sakshaug et al. 1997), and high-light inhibition may or may not be observed. At least 2 photosynthetic parameters characterize the $P-I$ response: $\alpha$, the initial slope of the light curve that characterizes photosynthetic efficiency at low irradiance, and $P_{\mathrm{m}}$, the plateau of the maximum photosynthetic rate at light saturation (Platt \& Sathyedranath 1993). In some instances, a third parameter $\beta$ is necessary to describe photoinhibition, the reduction in productivity at higher irradiance levels (Platt et al. 1980). The version of the equation used by Walsby (1997) includes plankton community respiration $\left(R_{\mathrm{c}}\right)$. This formulation is applicable only to oxygen determinations, since the ${ }^{14} \mathrm{C}$ method does not allow estimates of respiration (Platt \& Jassby 1976, Cote \& Platt 1983, Bender et al. 1987). Expressing these parameters in biomass-specific form, i.e. $\alpha^{B}$ and $P_{\mathrm{m}}^{B}$, removes the effect of standing stock so that these physiological parameters are independent of changes in biomass. The derived parameter $I_{\mathrm{k}}\left(=P_{\mathrm{m}}^{B}: \alpha^{B}\right)$ evaluates where the initial slope intersects the maximum, providing a useful measure of the light level at which photosynthesis is saturated (Figueiras et al. 1994).

Variation in the calculated biomass-specific photosynthetic parameters is used to characterize functional changes in the phytoplankton community, including physiological acclimation and shifts in community structure. Such variations provide quantitative insight into the effects of varying environmental conditions on specific phytoplankton production rates that are unresolved with the use of the measured volume-specific rates (Cote \& Platt 1983, 1984). Characterizing $P-I$ parameters in LIS enables synoptic estimates of the temporal and spatial variability in phytoplankton production for the first time (Goebel et al. 2006).

In this paper, we characterize the temporal and spatial variability of physiological parameters of the $P-I$ response $\left(\alpha^{B}, P_{\mathrm{m}}^{B}\right.$ and $\left.R_{\mathrm{c}}\right)$ from direct measurements of oxygen change in samples collected from central and western Long Island Sound (cwLIS) over 3 seasons during 2002 and 2003. We explore the relationships among phytoplankton metabolic rates and biomass, as well as their relationships to observed physical and chemical environmental parameters. Furthermore, we test the relationships between $R_{\mathrm{C}}$ and phytoplankton biomass or $P_{\mathrm{m}}^{B}$, to estimate an algal-related rate of respiration in LIS.

\section{MATERIALS AND METHODS}

Site description. Long Island Sound, typically divided into western, central and eastern segments, is $160 \mathrm{~km}$ long and 5 to $32 \mathrm{~km}$ wide, with a mean depth of $21 \mathrm{~m}$ and a bottom depth of 30 to $60 \mathrm{~m}$ throughout the central and western basins. The tide is predominantly semidiurnal (Wong 1990), with an average tidal amplitude that increases 4 -fold ( 0.7 to $2.1 \mathrm{~m}$ ) from the eastern to the western end of the Sound (http://co-ops.nos.noaa.gov/ tides05/tab2ec2a.html\#16). The turnover time for the entire Sound is 63 to $166 \mathrm{~d}$ (Turekian et al. 1996). Adjacent watersheds are highly populated, with more than 8 million people within the LIS drainage basin. In particular, the western end of LIS receives a large input of sewage from New York City and densely populated SW Connecticut. Salinity stratification begins during the inflow of freshwater from winter snow melt and spring rains. During the summer, physical stratification of the water column in central and western LIS (cwLIS) increases with increasing insolation and heating of surface waters (Welsh \& Eller 1991, Anderson \& Taylor 2001). Increased thermal stratification and relatively weak tidal and wind mixing inhibit ventilation of bottom water, leading to deteriorating oxygen levels (Welsh \& Eller 1991, Torgersen et al. 1997). Stratification and increasingly hypoxic conditions are usually disrupted by storms during autumn, and occasionally during summer (Anderson \& Taylor 2001).

Cruise plan. We sampled 8 stations spanning cwLIS during 15 surveys of 2 to 3 d; 6 stations were uniformly distributed along the main axis of cwLIS (Stns A4, C1/C2, D3, E1, F2/F3, H4) and 2 stations were transversely distributed (Stns 9, 15) (Fig. 1). Survey cruises were biweekly during the summers of 2002 and 2003 and monthly during autumn 2002, and late spring and autumn 2003.

Sampling regime. At each station, a Seabird SBE-19 SeaCat Profiler equipped with a YSI Model $5739 \mathrm{O}_{2}$ sensor, a spherical Licor PAR (photosynthetically active radiation) sensor, underwater model 193SA, and a WET Labs WETStar fluorometer was used to vertically profile salinity, temperature, dissolved oxygen, irradiance and chlorophyll fluorescence. The profiler was mounted on a General Oceanics Model 1015 rosette system that was also used to collect water at the surface (1 to $2 \mathrm{~m}$ ), mid-depth (within the pycnocline), and near bottom (1 to $2 \mathrm{~m}$ from the bottom). Discrete samples were filtered and analyzed for pigments; particulate $\mathrm{C}$ and $\mathrm{N}$ were also determined but are not reported here. Fluorometer and dissolved oxygen CTD data were calibrated with in situ water samples; these profile data were supplied by the State of Connecticut Department of Environmental Protection (CTDEP).

Underwater irradiance. Attenuation coefficients $\left(K_{i}\right.$ $\mathrm{m}^{-1}$ ) were calculated as the slope of the natural log of irradiance with depth (Kirk 1994). The depth of the photic zone $\left(Z_{\mathrm{p}}\right)$ was defined as $1 \%$ of subsurface $(0.2 \mathrm{~m})$ irradiance, so that $Z_{\mathrm{p}}=4.6 / \mathrm{K}$. Average irradiance within the photic zone $\left(\bar{I}_{Z_{\mathrm{p}}}\right)$ was calculated using the following equation (Kremer \& Nixon 1978): 


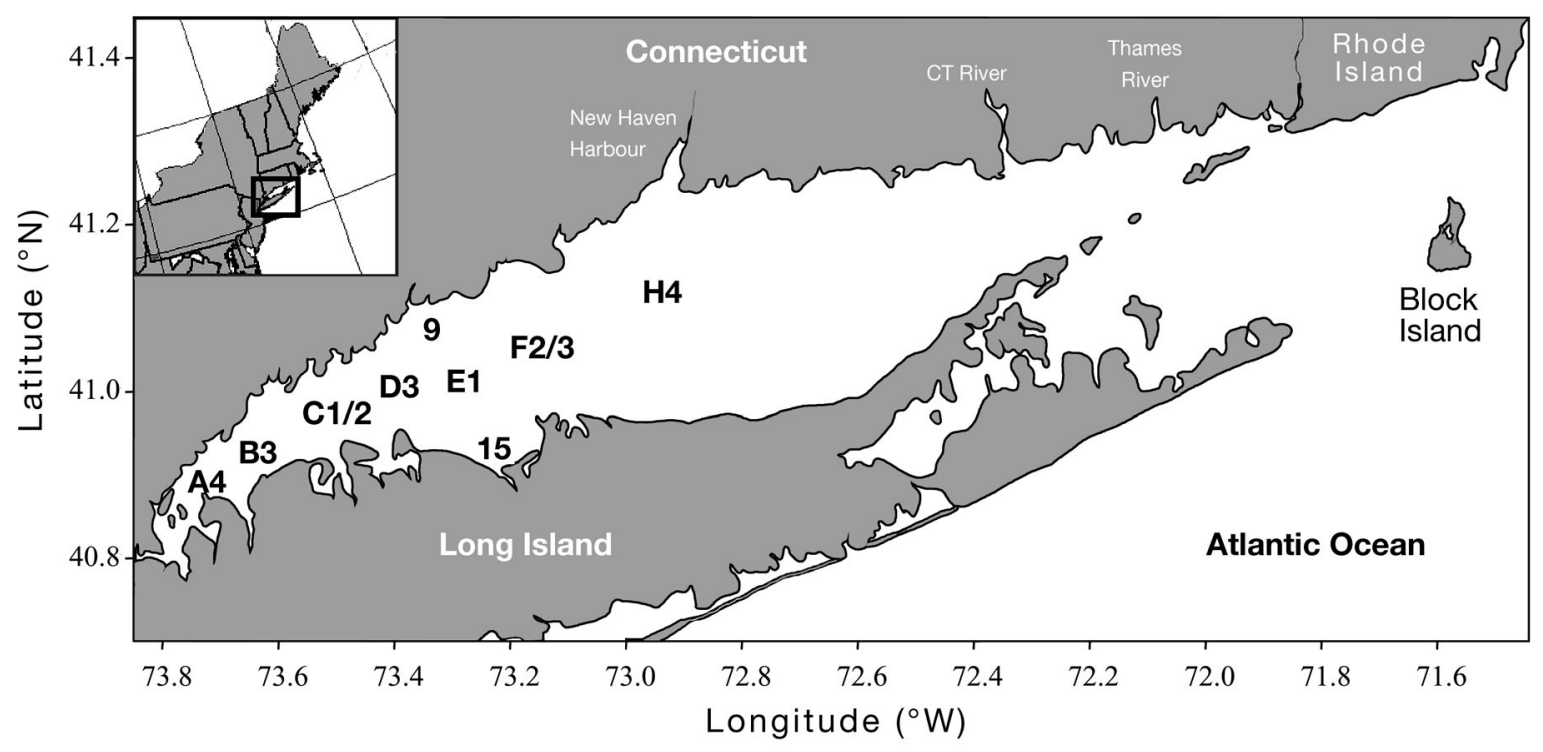

Fig. 1. Long Island Sound (LIS) and stations sampled. Inset: location of LIS on the NE coast of continental USA

$$
\bar{I}_{Z_{\mathrm{p}}}=I_{0}\left(1-\mathrm{e}^{-K Z \mathrm{p}}\right) /\left(K Z_{\mathrm{p}}\right)
$$

where $I_{0}$ is average daytime instantaneous incident irradiance $\left(\mu \mathrm{E} \mathrm{m} \mathrm{m}^{-2} \mathrm{~s}^{-1}\right)$. An analogous calculation was used for average irradiance in the mixed layer $\left(\bar{I}_{Z_{\mathrm{ml}}}\right)$ by replacing $Z_{\mathrm{p}}$ with $Z_{\mathrm{ml}}$ in Eq. (1). Depth of the mixed layer $\left(Z_{\mathrm{ml}}\right)$ was determined using density profiles from the CTD casts, and defined as the depth at which density $\left(\sigma_{t}\right)$ remains similar to that at the surface. Profiles of temperature, salinity and fluorescence from CTD casts were used to corroborate $Z_{\mathrm{ml}}$ when $\sigma_{t}$ was ambiguous. When stratification was not distinct, the criterion used to distinguish a stratified from a well-mixed water column was a density difference $\left(\sigma_{t}\right)$ between bottom (maximum) and surface (minimum) waters $<0.5 \mathrm{~kg} \mathrm{~m}^{-3}$ (Anderson \& Taylor 2001). In cases of a mixed water column $\left(\sigma_{t}<0.5 \mathrm{~kg} \mathrm{~m}^{-3}\right), Z_{\mathrm{ml}}$ equaled the entire depth of the water column.

Chlorophyll analysis. Triplicate samples of $250 \mathrm{ml}$ from each sampled depth were filtered in the field for chlorophyll (chl) concentration through GF/F filters, transported to the laboratory on ice, and frozen until analyzed (within $2 \mathrm{~d}$ ). Filters were extracted in $7 \mathrm{ml}$ of $90 \%$ acetone overnight (18 to $20 \mathrm{~h}$ ), mixed well, centrifuged, and read at room temperature fluorometrically before and after acidification with 2 drops of $10 \%$ $\mathrm{HCl}$. The Turner Designs Model TD-700 fluorometer was calibrated with pure chl a (semiannually) and a supplied solid standard (daily). Chl and phaeopigment (phaeo) concentrations were calculated with published equations (Parsons et al. 1984).

Productivity measurements. The $P-I$ parameters were determined for rates of change of dissolved oxy- gen $\left(\mathrm{O}_{2}\right)$ in light and dark bottles. The oxygen method provides several advantages over the more commonly used ${ }^{14} \mathrm{C}$ method in productive coastal waters. Unlike ${ }^{14} \mathrm{C}$, which appears to measure something between gross and net primary production (Bender et al. 1987), measurement of the changes in $\mathrm{O}_{2}$ enables the discrimination between net and gross production. This was also tested in the present study, in a comparison of $P-I$ curves derived from $\mathrm{O}_{2}$ and ${ }^{14} \mathrm{C}$ methods. Although the yield of biomass under nutrient-depleted conditions may not be represented by $\mathrm{O}_{2}$-based production, we do not consider this to be an issue in the nutrient replete waters of LIS. The $\mathrm{O}_{2}$ method also enables reliable measurements of plankton community respiration, a rate unattainable with ${ }^{14} \mathrm{C}$. Furthermore, $\mathrm{O}_{2}$ is of fundamental interest in the study of LIS hypoxia, and direct measurements in this currency make sense.

Metabolic rates were determined in $300 \mathrm{ml}$ borosilicate (Pyrex) BOD bottles. Bottles were filled with an unfiltered, homogenous sample of surface water from the upper mixed layer. Each $P-I$ series consisted of 12 light, 3 dark and 3 initial bottles. Triplicate darkincubated bottles and initial $\mathrm{O}_{2}$ concentrations were also measured on unfiltered samples from mid- and near-bottom depths. The BOD bottles were filled by overflowing with at least half a bottle volume, to avoid bubbles and air contamination. Bottles were stoppered before being placed in temperature-controlled incubators for 2 to $4 \mathrm{~h}$. Dark bottles were incubated in either an incubator cooled with surface water (observed temperature range was 2.5 to $25.6^{\circ} \mathrm{C}$ ) or an insulated box containing water from depths sampled (for pycnocline and bottom samples, the observed temperature range was 1.8 to $24.0^{\circ} \mathrm{C}$ ). Incubation tem- 
peratures were maintained within 2 to $3^{\circ} \mathrm{C}$ of in situ temperatures. Light bottles were placed in a flowthrough incubator cooled with surface water and illuminated with an Osram Sylvania Metalarc ${ }^{\circledR}$ (metal halide) lamp. Bottles were exposed to a light gradient encompassing the irradiance range of the photic zone in LIS, from $\sim 30$ to $1500 \mu \mathrm{E} \mathrm{m}^{-2} \mathrm{~s}^{-1}$. Light levels were achieved by different distances from the light source, in some cases modulated with mesh screening. Light levels were measured at the midpoint of a seawaterfilled BOD bottle at each position of the incubator with a spherical PAR sensor Biospherical Instruments underwater model QSP-2100 (3.7 pi collector). Initial and incubated BOD bottles were fixed with chemical reagents for the Winkler method (manganous sulfate and alkaline iodide; Parsons et al. 1984), stoppered, sealed with water around the neck, and capped, in order to avoid contamination of samples from evaporation and air exchange around the stopper, and returned to the laboratory for subsequent analysis (within $1 \mathrm{wk}$ ).

$\mathrm{O}_{2}$ analysis. Winkler titrations were carried out in the UCONN laboratory with a computer-controlled automatic titrator (Friederich 1991). This automated titrator analyzes the sample with a photometric detector to determine the endpoint at the wavelength of peak absorbance of the yellow iodide complex. Samples are titrated beyond the endpoint; the endpoint is determined as the intersection of linear regressions prior to and after the absorbance ceases to change with thiosulfate addition. A computer-controlled Kloehn digital pipette pump delivers increments down to $0.0005 \mathrm{ml}$ thiosulfate, a precision of $0.03 \mathrm{mmol} \mathrm{O}_{2} \mathrm{~m}^{-3}$. Replicate titrations with standards have a standard deviation of $0.06 \mathrm{mmol} \mathrm{O}_{2} \mathrm{~m}^{-3}(\mathrm{n}=5)$, far better than natural variability in our replicate field samples (standard deviation of $\sim 1 \mathrm{mmol} \mathrm{O}_{2} \mathrm{~m}^{-3}$ ).

$\boldsymbol{P}-\boldsymbol{I}$ curve-fitting procedure. Changes in net oxygen production of the plankton community (NCP) and consumption $\left(R_{\mathrm{C}}\right)$ in surface waters were normalized by average chl stock and plotted as a function of irradiance. Various equations have been used to model $P-I$ data, resulting in substantial testing and discussion of their relative merits (Platt \& Jassby 1976, Aalderink \& Jovin 1997, Gilbert et al. 2000). Aalderink \& Jovin (1997) and Gilbert et al. (2000) tested the variability of different model fits. Aalderink \& Jovin (1997) demonstrated that the 8 models they compared could not be distinguished by their goodness of fit at the $90 \%$ level of confidence. Gilbert et al. (2000) also found that no model was superior, emphasizing that comparison of data sets should use the same model. We initially evaluated 4 models for calculated net photosynthetic rate of the community $\left(P_{\mathrm{c}}\right)$ : (Webb et al. 1974, Jassby \& Platt 1976, Platt et al. 1980, Walsby 1997). The following model was chosen from Platt et al. (1980), as modified by Walsby (1997), to include photoinhibition.

$$
P_{\mathrm{c}}=P_{\mathrm{m}}^{B}\left[1-\exp \left(-\alpha^{B} \frac{I}{P_{\mathrm{m}}^{B}}\right)\right]-R_{\mathrm{c}}^{B}+(\beta I)
$$

This model fit our data well and was also used by Walsby (1997) for rates of production using oxygen evolution including a chlorophyll-normalized parameter for oxygen consumption $\left(R_{\mathrm{C}}^{B}\right)$. The interpretation of $R_{\mathrm{C}}^{B}$ is questionable, so the more meaningful $R_{\mathrm{C}}$ was fitted to Eq. (2) utilizing non-chlorophyll-specific (i.e. volumetric) oxygen change data (i.e. $\alpha$ and $P_{\mathrm{m}}$ ).

The non-linear Levenberg-Marquardt curve-fitting algorithm (FIT) and confidence interval (CONFINT) functions in Matlab ${ }^{\circledR}$ were used to fit the $P-I$ model to our data yielding estimates with $95 \%$ confidence intervals for biomass-specific $P-I$ parameters $\left(\alpha^{B}\right.$ and $\left.P_{\mathrm{m}}^{B}\right)$ and community respiration $\left(R_{\mathrm{C}}\right)$. This curve fitting procedure requires initial estimates, but no specific constraints, for the adjusted parameters. Photoinhibition was not observed and $\beta$ was set equal to zero. With no necessary correction for $\beta$, the fitted $P_{\mathrm{m}}^{B}$ represents the maximum realized instantaneous gross community production (Platt et al. 1980). Selection of $P-I$ curves was based on goodness of fit. The criterion of adjusted $\mathrm{r}^{2}>70 \%$ resulted in the removal of $10 \%$ of the $P-I$ curves. An average coefficient of variation was calculated for the fit of each parameter to the model (Eq. 2). Comparison of $R_{\mathrm{C}}$ measured directly as the average of 3 dark incubations and $R_{\mathrm{c}}$ modeled with the $P-I$ curve fitting procedure demonstrated good agreement $\left(\mathrm{r}^{2}=\right.$ 0.97, $\mathrm{p}<0.0001, \mathrm{n}=98$ ), well within the standard errors of replicate BOD bottle measurements and $P-I$ curve fits; here modeled values are used.

Spectral quality. To quantify potential effects of the spectral quality of the artificial light incubator, results from the on-deck system were compared to simultaneous incubations run in situ at a central station (C1/C2 in Fig. 1). Trials on 2 dates indicated no significant differences between the calculated $P-I$ parameters fitted on the $P-I$ data from samples incubated on-deck versus in situ. In the first trial, $\alpha^{B}$ and $P_{\mathrm{m}}^{B}$ values and their calculated standard deviations from the fitted $P-I$ curves of the in situ and incubated arrays were not significantly different, falling well within the range of variability observed throughout the remainder of this study. Although the parameters were also not significantly different in the second experiment, large variability in the slopes of each curve made it difficult to determine whether $\alpha^{B}$ was actually not significantly different between the 2 methods. Despite the inconclusive comparison of $\alpha^{B}$ in Trial 2, there were no significant effects of spectral quality on our in situ incubations based on our measurements of $P_{\mathrm{m}}^{B}$ in both trials, and $\alpha^{B}$ in the first trial. 
Diurnal variability. Since incubations from different stations were initiated at varying times throughout the day, there was a potential bias due to diurnal variations in $P-I$ parameters (Harding et al. 1981, 1982). Possible diurnal effects were investigated in our $P-I$ measurements on 2 occasions during the summer of 2002. A bulk water sample ( 20 l) was collected in the morning ( 08:00 h), and held in large (20 l) polycarbonate bottles under subdued light for the remainder of the day. We sampled 3 overlapping $P-I$ series and chlorophyll standing stock measurements from this reference sample throughout the daily survey (09:00 to 17:00 h).

No trends in diurnal variability were observed over 2 trial experiments. One of the experiments demonstrated no significant differences among fitted $P-I$ parameters throughout the period of the day. In the other experiment, significant differences occurred, with a minimum $\alpha^{B}$ in the morning, a minimum $P_{\mathrm{m}}^{B}$ mid-day, and a maximum $P_{\mathrm{m}}^{B}$ in the late afternoon. These results were inconclusive and no obvious correction seems justified. In any case, seasonal, spatial and overall averages for $P-I$ parameters were measured at a variety of initial sampling times during the photoperiod with no systematic bias. Therefore any daytime variations in productivity, which might vary with likely but uninvestigated species composition and/or environmental conditions (Harding et al. 1981), are included in the seasonal and annual variability we report.

Statistics. Descriptive statistics (mean, standard deviation, coefficient of variation, range, median, quartiles and range factor (=maximum/minimum) were calculated for $P-I$ parameters, $R_{\mathrm{C},} \mathrm{chl}$, phaeo, and irradiance variables measured in this study (see Tables 1 \& 2). Statistical descriptors of $P-I$ parameters and respiration exclude outliers ( $>3$ interquartile ranges from the edge of the interquartile range; SPSS v12.0.1). These outliers for fitted parameters are indicated in box plots that display temporal variability (see Figs. 2 \& 5), but omitted from plots displaying spatial variability (see Figs. $3 \& 6$ ) and from all statistical tests. Survey-wide averages of variables in the text are reported $\pm \mathrm{SD}$, while fitted parameters of linear and non-linear models are reported $\pm \mathrm{SE}$ of the estimate.

ANOVA comparisons of the natural log transformations of physiological parameters $\left(\alpha^{B}, P_{\mathrm{m}}^{B}, R_{\mathrm{c}}\right.$ and $I_{\mathrm{k}}$ ), chl and phaeo, and irradiance variables ( $K$ or $Z_{\mathrm{p}}, Z_{\mathrm{ml}}, \bar{I}_{Z_{\mathrm{p}}}$ and $\left.\bar{I}_{Z_{\mathrm{ml}}}\right)$ were used to test for significant differences, indicated by p-values, in time (month and year) and space (station) (see Table 3). Although natural log transformations improved the normality of the data, Levene's statistical test was significant across all ANOVAs, indicating heterogeneous variances. However, van Belle (2002) states that the Levene's statistic is very sensitive to departures from the assumption of homoscedasticity and should not prohibit further hypothesis testing. Therefore we proceeded with the multi-way ANOVA. In instances where there were no significant interactions within the 3-way ANOVA, we checked for significant differences among nonhomoscedasctic variables using 1-way ANOVA and the Welch and Brown-Forsyth robust tests of equality of means (SPSS v12.0.1). This secondary check reversed the significance for monthly variability in light attenuation properties ( $K$ or $Z_{\mathrm{p}}$ and $Z_{\mathrm{ml}}$ ) only (see Table 3).

With uncertainties in both variables, we applied a weighted Model II linear least squares regression, following Press et al. (1992), to estimate the average relationship between $R_{\mathrm{c}}$ and chl. Log-transformation may improve the Gaussian distributions of regressed variables (e.g. Robinson \& Williams 2005, p. 159), however, the log-transformed regression model did not improve the fit of our data or the normal distribution of the residuals. Regression of non-transformed variables resulted in the best model fit, and normality of the data and residuals met the assumptions of this analysis.

Rates of oxygen production expressed in carbon (C) units are converted assuming a photosynthetic quotient (PQ) of 1.2. This PQ falls within the lower range of $P Q$ for ammonium-driven production (Laws 1991). We base our estimated PQ on reports of ammonium as the primary nitrogen source for productivity in the western end of LIS (Anderson \& Taylor 2001), which agrees with the direct measurements of Oviatt et al. (1986) in the waters of nearby Narragansett Bay, Rhode Island.

\section{RESULTS}

\section{Surface waters}

\section{Physical environment}

Temporal trends. Temperature and salinity varied seasonally reaching their maxima in mid- to late-summer (Fig. 2). Surface temperatures ranged from a low of $2.5^{\circ} \mathrm{C}$ (May 2002) to highs in late August of $23.8^{\circ} \mathrm{C}$ in 2002 and $25.6^{\circ} \mathrm{C}$ in 2003 . Variations in surface salinity lagged behind temperature, with lowest observed salinities through May (24.9) and June (23.8) of 2003 and highs in early October of 2002 (28.6) and 2003 (28.1). Interannual differences in average surface temperature throughout LIS for the 2 summers were not significant, however average surface salinity throughout LIS in the summer of 2003 was significantly lower than that in summer $2002(\mathrm{p}<0.001, \mathrm{n}=31)$. Thermal stratification of the water column increased continuously during both summers, accompanied by continually decreasing bottom water oxygen concentrations 


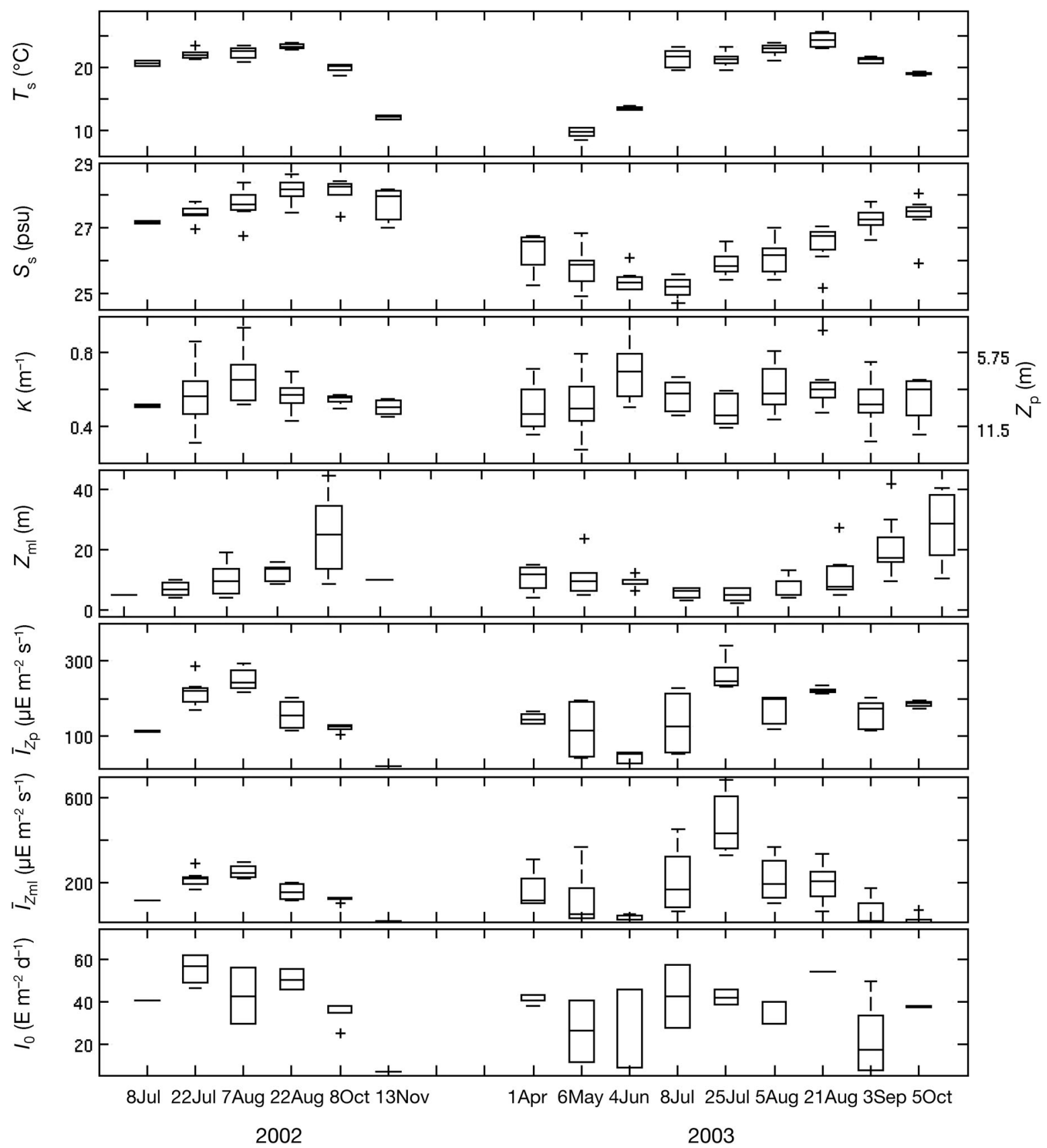

Fig. 2. Spatially averaged box-plots demonstrating seasonal (temporal) variation in surface $(2 \mathrm{~m})$ temperature $\left(T_{\mathrm{s}},{ }^{\circ} \mathrm{C}\right)$ and salinity $\left(S_{\mathrm{s}}, \mathrm{psu}\right)$, light-attenuation $\left(K, \mathrm{~m}^{-1}\right)$ and in photic depth $\left(Z_{\mathrm{p}}, \mathrm{m}\right.$ on right-hand ordinate), mixed-layer depth $\left(Z_{\mathrm{ml}}, \mathrm{m}\right)$, average irra-

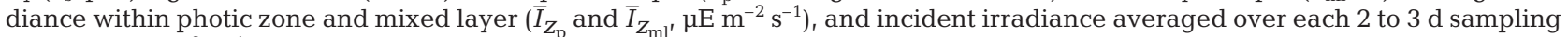
period $\left(I_{0}, \mathrm{E} \mathrm{m}^{-2} \mathrm{~d}^{-1}\right)$. Lower and upper lines of each box $=25$ th and 75th percentiles of sample, respectively; distance between top and bottom of box: interquartile range; line through middle of box: sample median (when off-center indicates skewness); vertical lines extending above and below box show extent of rest of sample minus outliers: assuming no outliers, maximum and minimum of sample are upper and lower bars across ends of vertical lines; +: outliers

(not shown). Wind and storm events disrupted the pycnocline and alleviated the hypoxic conditions of bottom waters in late September to early October of 2002 and 2003. (Trends in bottom water oxygen concentrations for these times can be seen in results of the
CTDEP hypoxia cruises at http://dep.state.ct.us/wtr/ lis/monitoring/lis_page.htm.)

Significant monthly variations were apparent in light attenuation in the water column $(K)$, depth of the photic zone $\left(Z_{\mathrm{p}}\right)$, depth of the mixing layer $\left(Z_{\mathrm{ml}}\right)$, aver- 
age daytime irradiance within the photic zone and mixing layer $\left(\bar{I}_{Z_{\mathrm{p}}} \bar{I}_{Z_{\mathrm{ml}}}\right)$, and incident daily irradiance $\left(I_{0}\right)$ (Fig. 2). The highest $\bar{I}_{Z_{\mathrm{p}}}, \bar{I}_{Z_{\mathrm{ml}}}$ and $I_{0}$ occurred during the summer of both years. A seasonal increase in $K$ (and a decrease in $Z_{\mathrm{p}}$ ) was more apparent during the summer of 2002 than 2003 (Fig. 2). These descriptors of underwater irradiance $\left(K\right.$ and $Z_{\mathrm{p}}$ ) exhibited steep, significant along-Sound gradients (see next subsection and Fig. 3) that confounded the apparent significance of average seasonal (monthly) trends (see Table 3). During the periods sampled, incident irradiance integrated over the day $\left(I_{0 ;}\right.$ Fig. 2) ranged from the mid-summer peak in late July $\left(60 \mathrm{E} \mathrm{m}^{-2}\right.$ $\left.\mathrm{d}^{-1}\right)$ to a minimum in May $2003\left(11 \mathrm{E} \mathrm{m}^{-2}\right.$ $\mathrm{d}^{-1}$ ). Observed photoperiods based on local incident irradiance data (not shown) ranged from $10 \mathrm{~h}$ (November 2002) to $17 \mathrm{~h}$ (June 2003).

Spatial trends. Spatial trends in temperature and salinity demonstrated small but consistent along-Sound gradients throughout the study, with lowest salinities and highest temperatures at the head (innermost western end) of the Sound (Fig. 3). These along-Sound gradients were strongest in mid-summer.

Significant along-Sound gradients in $K$ (and $Z_{\mathrm{p}}$ ) were also apparent throughout the study (see Table 3), with highest attenuation $\left(0.9\right.$ to $\left.1.0 \mathrm{~m}^{-1}\right)$ at the innermost station during mid-summer of 2002 and early and late summer of 2003. Throughout the study, $K$ ranged from 0.5 to $1.0 \mathrm{~m}^{-1}$ at the innermost station and 0.3 to $0.6 \mathrm{~m}^{-1}$ at the outermost station, averaging $0.6 \pm 0.1 \mathrm{~m}^{-1}$ for all irradiance profiles (Table 1). Photic zone depth $\left(Z_{\mathrm{p}}\right)$ averaged $8.7 \pm 2.1 \mathrm{~m}$ for all observed irradiance profiles (Table 1) and resided within the depth of the upper mixed layer for approximately half of the observation period (average $Z_{\mathrm{ml}}=12.0 \pm$ $9.2 \mathrm{~m})$. These values for $Z_{\mathrm{p}}$ and $Z_{\mathrm{ml}}$ compare well with respective ranges of 5 to $11 \mathrm{~m}$ and 4 to $15 \mathrm{~m}$ measured at Stn A4 by Anderson \& Taylor (2001).

\section{$P-I$ parameters and pigments}

Overall trends. Fig. 4 shows 9 representative $P-I$ curves to demonstrate and compare variability in fitted $P-I$ parameters $\left(\alpha^{B}\right.$ and $\left.P_{\mathrm{m}}^{B}\right)$. These examples were
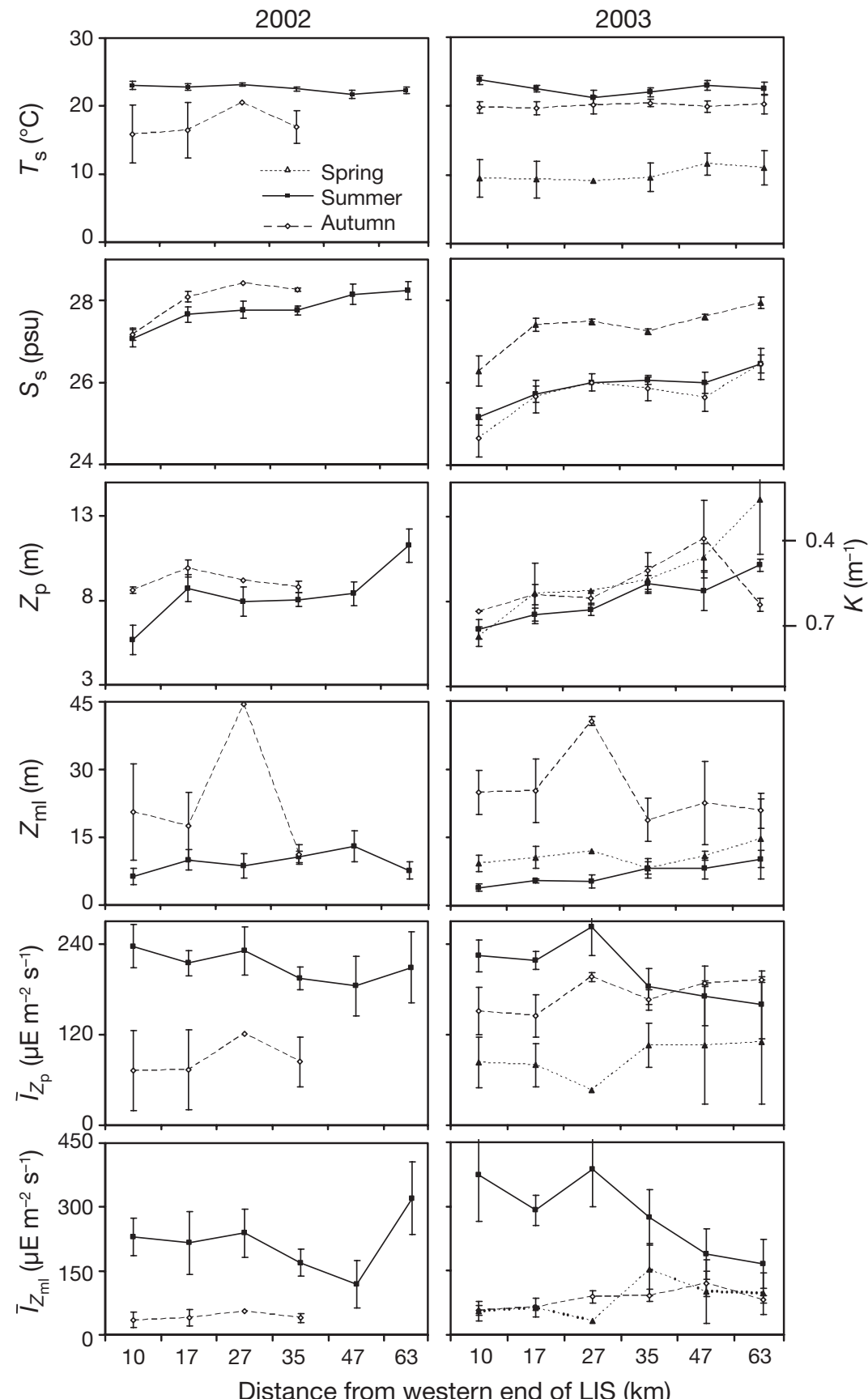

Fig. 3. Mean \pm SE interannual and spatial variation in surface temperature $\left(T_{\mathrm{s}}{ }^{\circ} \mathrm{C}\right)$ and salinity $\left(S_{\mathrm{s}}, \mathrm{psu}\right)$, photic depth $\left(Z_{\mathrm{p}}, \mathrm{m}\right)$ and light attenuation $\left(K, \mathrm{~m}^{-1}\right.$, on right-hand ordinate), mixed-layer depth $\left(Z_{\mathrm{ml}}, \mathrm{m}\right)$ and average irradiance within photic zone and mixed layer $\left(\bar{I}_{Z_{\mathrm{p}}}\right.$ and $\bar{I}_{Z_{\mathrm{ml}}}$

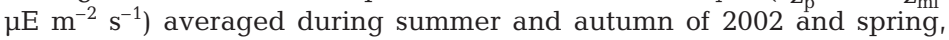
summer and autumn of 2003. Outliers ( $>3$ interquartile ranges) omitted measured in the summers of 2002 and 2003 and autumn 2003 at 3 stations along the axis of cwLIS: inner (A4), mid (C1/2) and outer (H4) (Fig. 1). The $P-I$ parameters did not vary consistently with space.

Across the entire data set (minus outliers) $P_{\mathrm{m}}^{B}$ demonstrated the lowest variability (range factor) com- 
Table 1. Mean, standard deviation (SD), coefficient of variation for entire data set (CV), range, median and percentiles (minimum, $25 \%$, median, $75 \%$, maximum), number of samples (n), and range factors ( $x$-fold) over entire sampling duration for variables: $P-I$ parameters $\left(\alpha^{B}, P_{\mathrm{m}}^{B}, I_{\mathrm{k}}=P_{\mathrm{m}}^{B} / \alpha^{B}\right)$, light-attenuation $(K)$, photic depth $\left(Z_{\mathrm{p}}\right)$, mixed layer depth $\left(Z_{\mathrm{ml}}\right)$ and average irradiance in the photic zone $\left(\bar{I}_{Z_{\mathrm{p}}}\right)$ and mixed layer $\left(\bar{I}_{Z_{\mathrm{ml}}}\right)$. Range factors $(x$-fold) are also calculated for each season. Outliers (defined as 3 interquartile ranges from edge of interquartile range) omitted from estimates of fitted parameters. See 'Materials and methods' for parameter units

\begin{tabular}{|c|c|c|c|c|c|c|c|c|}
\hline & $\alpha^{B}$ & $P_{\mathrm{m}}^{B}$ & $I_{\mathrm{k}}$ & $K$ & $Z_{\mathrm{p}}$ & $Z_{\mathrm{ml}}$ & $\bar{I}_{Z_{\mathrm{p}}}$ & $\bar{I}_{Z_{\mathrm{ml}}}$ \\
\hline Mean & 10.9 & 1.3 & 132.6 & 0.6 & 8.7 & 12.0 & 168.6 & 178.9 \\
\hline $\mathrm{SD}$ & 5.4 & 0.4 & 71.9 & 0.1 & 2.1 & 9.2 & 73.0 & 144.8 \\
\hline $\mathrm{CV}$ & 0.5 & 0.3 & 0.5 & 0.2 & 0.2 & 0.8 & 0.4 & 0.8 \\
\hline Minimum & 2.1 & 0.3 & 40.7 & 0.3 & 4.2 & 2.0 & 19.5 & 17.2 \\
\hline $25 \%$ & 7.2 & 1.0 & 79.9 & 0.5 & 7.4 & 6.0 & 121.2 & 67.0 \\
\hline Median & 10.3 & 1.2 & 113.2 & 0.6 & 8.4 & 9.1 & 188.1 & 126.3 \\
\hline $75 \%$ & 14.1 & 1.4 & 172.5 & 0.6 & 9.6 & 15.0 & 220.0 & 272.6 \\
\hline Maximum & 29.5 & 2.5 & 349.2 & 1.0 & 17.2 & 44.4 & 338.8 & 682.1 \\
\hline $\mathrm{n}$ & 91 & 96 & 97 & 98 & 98 & 98 & 98 & 98 \\
\hline Range factor ( $x$-fold): All & 14 & 5 & 9 & 3 & 4 & 22 & 17 & 40 \\
\hline Summer $2002 \quad(n=23)$ & 5 & 3 & 4 & 3 & 3 & 7 & 2 & 9 \\
\hline Summer $2003 \quad(n=30)$ & 8 & 3 & 5 & 2 & 2 & 4 & 12 & 30 \\
\hline Autumn $2002 \quad(n=6)$ & 10 & 2 & 5 & 1 & 1 & 5 & 7 & 4 \\
\hline Autumn $2003 \quad(\mathrm{n}=13)$ & 2 & 2 & 2 & 2 & 2 & 5 & 2 & 4 \\
\hline Spring $2003 \quad(n=7)$ & 4 & 3 & 7 & 2 & 2 & 6 & 5 & 11 \\
\hline
\end{tabular}

Table 2. Statistical descriptors (as in column 1 of Table 1) for chlorophyll (chl), phaeopigments (phaeo), phaeo:chl and community respiration $\left(R_{\mathrm{c}}\right)$ at surface, mid and bottom depths. Subscripts designate surface $\left({ }_{\mathrm{s}}\right)$, mid $(\mathrm{m})$ and bottom $(\mathrm{b})$ depths. Units for chl and phaeo (except for phaeo:chl) are $\mathrm{mg} \mathrm{m}^{-3}$, units for $R_{\mathrm{c}}$ are $\mathrm{mmol} \mathrm{O}_{2} \mathrm{~m}^{-3} \mathrm{~h}^{-1}$

\begin{tabular}{|c|c|c|c|c|c|c|c|c|c|c|c|c|}
\hline & $\mathrm{Chl}_{\mathrm{s}}$ & $\mathrm{Chl}_{\mathrm{m}}$ & $\mathrm{Chl}_{\mathrm{b}}$ & $\mathrm{Phaeo}_{\mathrm{s}}$ & $\mathrm{Phaeo}_{\mathrm{m}}$ & $\mathrm{Phaeo}_{\mathrm{b}}$ & Phaeo: $\mathrm{chl}_{\mathrm{s}}$ & Phaeo:chl $\mathrm{m}$ & Phaeo:chl & $R_{\mathrm{C}_{\mathrm{S}}}$ & $R_{\mathrm{C}_{\mathrm{m}}}$ & $R_{\mathrm{C}_{\mathrm{b}}}$ \\
\hline Mean & 6.9 & 3.0 & 1.7 & 3.5 & 2.3 & 1.9 & 0.7 & 0.9 & 1.5 & 1.4 & 0.8 & 0.7 \\
\hline $\mathrm{SD}$ & 4.9 & 1.6 & 1.0 & 2.5 & 1.1 & 0.9 & 0.9 & 0.6 & 1.1 & 0.9 & 0.6 & 0.5 \\
\hline $\mathrm{CV}$ & 0.7 & 0.5 & 0.6 & 0.7 & 0.5 & 0.5 & 1.2 & 0.7 & 0.7 & 0.6 & 0.7 & 0.7 \\
\hline Minimum & 2.1 & 0.5 & 0.3 & 0.9 & 0.6 & 0.3 & 0.2 & 0.3 & 0.1 & 0.1 & 0.0 & 0.0 \\
\hline $25 \%$ & 3.5 & 1.9 & 0.9 & 1.9 & 1.4 & 1.3 & 0.4 & 0.5 & 0.9 & 0.7 & 0.5 & 0.3 \\
\hline Median & 5.6 & 2.9 & 1.8 & 2.7 & 2.1 & 1.6 & 0.5 & 0.7 & 1.2 & 1.4 & 0.7 & 0.6 \\
\hline $75 \%$ & 7.6 & 3.7 & 2.5 & 4.6 & 2.6 & 2.5 & 0.7 & 1.3 & 1.6 & 1.9 & 1.2 & 1.0 \\
\hline Maximum & 24.1 & 8.7 & 4.2 & 12.4 & 5.7 & 4.8 & 6.3 & 3.0 & 6.2 & 4.0 & 2.8 & 1.9 \\
\hline $\mathrm{n}$ & 98 & 98 & 98 & 98 & 98 & 97 & 98 & 96 & 96 & 88 & 76 & 76 \\
\hline Range factor ( $x$-fold): All & 11 & 19 & 14 & 14 & 9 & 15 & 27 & 10 & 56 & 28 & 90 & 60 \\
\hline Summer $2002 \quad(n=23)$ & 8 & 6 & 10 & 5 & 9 & 11 & 3 & 9 & 58 & 10 & 1 & 1 \\
\hline Summer $2003 \quad(\mathrm{n}=30)$ & 8 & 19 & 11 & 14 & 4 & 8 & 27 & 9 & 6 & 16 & 114 & 33 \\
\hline Autumn 2002 & 2 & 5 & 10 & 3 & 4 & 12 & 3 & 2 & 4 & 2 & 16 & 30 \\
\hline Autumn 2003 & 3 & 2 & 3 & 3 & 2 & 2 & 4 & 3 & 4 & 7 & 3 & 4 \\
\hline Spring $2003 \quad(n=7)$ & 9 & 3 & 4 & 2 & 4 & 4 & 1 & 2 & 1 & 12 & 4 & 3 \\
\hline
\end{tabular}

pared to chl and phaeo concentrations, $\alpha^{B}, I_{\mathrm{k}}$ and $R_{\mathrm{C}}$ (Tables 1 \& 2). Coefficients of variation for the averages over the entire data set were lowest for $P_{\mathrm{m}}^{B}$ and highest for chl and $R_{\mathrm{C}}$, with $\alpha^{B}$ intermediate. The average coefficient of variation associated with the error in the fit of the $P-I$ model (Eq. 2) for $\alpha^{B}(0.7)$ was almost 3 times greater than that of $P_{\mathrm{m}}^{B}(0.25) . P_{\mathrm{m}}^{B}$ averaged $1.3 \pm 0.4 \mathrm{mmol} \mathrm{O}_{2}[\mathrm{mg} \mathrm{chl}]^{-1} \mathrm{~h}^{-1}$ (equivalent to $1.0 \pm$ $3.1 \mathrm{mmol} \mathrm{C}\left[\mathrm{mg} \mathrm{chl}^{-1} \mathrm{~h}^{-1}\right.$ ) and varied 5-fold. Chl averaged $6.9 \pm 4.9 \mathrm{mg} \mathrm{m}^{-3}$ and varied 11-fold. $\alpha^{B}$ averaged $10.9 \pm 5.4 \mu \mathrm{mol} \mathrm{O}{ }_{2}\left[\mathrm{mg} \mathrm{chl}^{-1} \mathrm{~h}^{-1}\left(\mu \mathrm{E} \mathrm{m}^{-2} \mathrm{~s}^{-1}\right)^{-1}\right.$ (equiva-

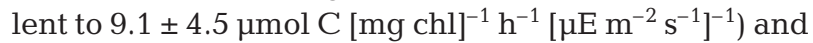

varied 14-fold. As expected, the range factor of modelfitted parameters and environmental variables was narrower for specific seasons (Tables $1 \& 2$ ).

In a multivariate ANOVA, comparisons varied significantly among sampled years (2002 vs. 2003) for $\alpha^{B}, R_{\mathrm{C}}$ and $I_{\mathrm{k}}$, but not for chl, phaeo or $P_{\mathrm{m}}^{B}$ (Table 3). Among summers only, ANOVA indicated significant interannual variation for $\alpha^{B}(\mathrm{p}<0.001), R_{\mathrm{C}}(\mathrm{p}<0.040)$ and $I_{\mathrm{k}}$ ( $\mathrm{p}<0.001)$, but not chl, phaeo, or $P_{\mathrm{m}}^{B}$. All $P-I$ parameters and pigment concentrations varied significantly with month. Along the length of the Sound (by station) concentrations of chl and phaeo and rates of commu- 
Table 3. A 3-way ANOVA for natural log-transformed photosynthetic parameters $\left(\alpha^{B}\right.$ and $\left.P_{\mathrm{m}}^{B}\right)$, community respiration $\left(R_{\mathrm{c}}\right)$, chlorophyll (chl), phaeopigments (phaeo), $I_{\mathrm{k}}$ and irradiance variables ( $K$ and $Z_{\mathrm{p}}, Z_{\mathrm{ml}}, \bar{I}_{Z_{\mathrm{p}}}$ and $\bar{I}_{Z_{\mathrm{ml}}}$ ) measured in surface waters along the main transect of the Sound by station $(n=8)$, by month $(n=8)$ and by year $(n=2)$. Significant Levene's test $(p<0.001)$ rejected equality of the variances for all ANOVA tests, therefore significant differences were checked with 1-way ANOVA and Welch \& Brown-Forsyth robust tests of equality of means. The only multivariate ANOVA statistics that did not hold in the 1-way ANOVA (hence deemed non-significant) were monthly variation in $K$ and $Z_{\mathrm{p}}$ and spatial variation for $Z_{\mathrm{ml}}$ (italicized showing both results). Values in boldface: significant at $\mathrm{p}<0.05$ level. Outliers omitted

\begin{tabular}{|c|c|c|c|c|c|c|c|c|c|c|}
\hline Source & $\ln \alpha^{B}$ & $\ln P_{m}^{B}$ & $\ln R_{\mathrm{C}}$ & $\ln \mathrm{Chl}$ & ln Phaeo & $\ln I_{\mathrm{k}}$ & $K \& Z_{\mathrm{p}}$ & $Z_{\mathrm{ml}}$ & $\ln \bar{I}_{Z_{\mathrm{ml}}}$ & $\ln \bar{I}_{Z_{\mathrm{p}}}$ \\
\hline Site & 0.62 & 0.08 & $<0.001$ & $<0.001$ & $<0.001$ & 0.90 & $<0.001$ & $<0.001 / 0.24$ & 0.32 & 0.98 \\
\hline Month & $<0.001$ & $<0.001$ & $<0.001$ & $<0.001$ & $<0.001$ & $<0.001$ & $<0.01 / 0.08$ & $<0.001$ & $<0.001$ & $<0.001$ \\
\hline Year & 0.02 & 0.08 & $<0.001$ & 0.31 & 0.28 & 0.03 & 0.69 & 0.46 & 0.54 & 0.74 \\
\hline Site $\times$ Month & 0.29 & 0.03 & 0.38 & 0.33 & 0.09 & 0.39 & 0.93 & 0.02 & 0.63 & 0.97 \\
\hline Site $\times$ Year & 0.66 & 0.02 & 0.44 & 0.56 & 0.03 & 0.30 & 0.62 & 0.57 & 0.58 & 0.93 \\
\hline Month $\times$ Year & 0.10 & 0.02 & $<0.01$ & 0.41 & 0.16 & 0.22 & 0.63 & 0.95 & 0.87 & 0.53 \\
\hline Site $\times$ Month $\times$ Year & 0.29 & 0.25 & 0.28 & 0.50 & 0.10 & 0.53 & 0.99 & 0.31 & 0.99 & 0.89 \\
\hline
\end{tabular}

nity respiration $\left(R_{\mathrm{c}}\right)$ varied significantly. However, ANOVA tests revealed no significant spatial variability in $\alpha^{B}, P_{\mathrm{m}}^{B}$ or $I_{\mathrm{k}}$ (Table 3 ).

Temporal trends. Spatially averaged surface chl and phaeo concentrations and $P-I$ parameters $\left(P_{\mathrm{m}}^{B}, \alpha^{B}\right.$ and $I_{\mathrm{k}}$ ) increased significantly during spring and summer seasons (Fig. 5, Table 3). Chl and phaeo concentrations peaked in late July to early August of 2002 and 2003 and in late spring (May) of 2003. (Note that our cruises did not sample December through March, thus missing a possible winter-spring bloom.) $P_{\mathrm{m}}^{B}$ increased significantly during both summer periods, with maxima in late August of 2002 and 2003. Although monthly trends in $\alpha^{B}$ were less clear-cut than in chl and $P_{\mathrm{m}}^{B}$ $\alpha^{B}$ did peak and correlate with $P_{\mathrm{m}}^{B}(\mathrm{r}=0.380, \mathrm{p}<0.001$, $\mathrm{n}=90$; see later subsection) and varied significantly by month (Table 3) due to the extremes of summer maxima (June and August 2003) and an autumn minimum (November 2002). $I_{\mathrm{k}}$ varied significantly throughout the observation period. A seasonal peak was more apparent during the summer of 2003; however, the maximum $I_{\mathrm{k}}$ was observed in November 2002. $R_{\mathrm{c}}$ increased significantly during late summer to early autumn ( $\mathrm{p}$ 0.0001). The maximum ratio of phaeo:chl (not shown) was detected in the following sampling period ( $2 \mathrm{wk}$ ) after the summer chl peaks.

Spatial trends. Chl and phaeo decreased seaward along the length of LIS consistently during each sampling period, as demonstrated by seasonal averages (Fig. 6). During the height of each summer bloom (late July to early August), maximum chl concentrations at the head of the Sound decreased seawards 5-fold (2002) to 7 -fold (2003) toward the outermost station, in central LIS. This gradient was either diminished or not evident during sampled periods of low biomass. In contrast, variability was insignificant along the Sound for biomass-specific $P-I$ parameters $\left(P_{\mathrm{m}}^{B}, \alpha^{B}\right.$, and $\left.I_{\mathrm{k}}\right)$ on most cruises (Fig. 6, Table 3).
Inter-relationships among $P-I$ parameters, pigments and physical environment

$P-I$ parameters versus chl. Chl measured in surface waters was not significantly correlated with $\alpha^{B}$ or $P_{\mathrm{m}}^{B}$ for the entire data set (Table 4). However, changes in the relationships between $\mathrm{chl}$ and $P-I$ parameters could be identified for some seasons (Fig. 7). Different clusters of $P_{\mathrm{m}}^{B}$ with chl were apparent, particularly during late summer and spring (Fig. 7A). In contrast, seasonal groups of $\alpha^{B}$ with chl were less apparent due to the overlapping of clusters, which distinguished high chl periods (late summer and spring) from low chl periods (early summer and autumn; Fig. 7B). The relationship between $\alpha^{B}$ and $P_{\mathrm{m}}^{B}$ varied with season (Fig. 7C). The slopes of $P_{\mathrm{m}}^{B}$ versus $\alpha^{B}$ for each season were significant but indistinguishable from each other except for a 2-fold increase in late summer (Fig. 7C).

$P-I$ parameters versus irradiance variables. Correlations between $P-I$ parameters, chl, temperature, and irradiance values are summarized in Table 4 . Of interest is a significant correlation between $\alpha^{B}$ and the depth of the mixed layer $\left(Z_{\mathrm{ml}}\right)$, but not with the depth of the $1 \%$ light level $\left(Z_{\mathrm{p}}\right)$. In contrast, $P_{\mathrm{m}}^{B}$ correlated significantly with $Z_{\mathrm{p}}$ but not with $Z_{\mathrm{ml}}$.

Average daytime irradiance in the photic zone $\left(\bar{I}_{Z_{\mathrm{p}}}\right)$ and in the mixed layer $\left(\bar{I}_{Z_{\mathrm{ml}}}\right)$ were comparable when averaged across the study (Table 1), however $\bar{I}_{Z_{\mathrm{ml}}}$ was more variable (Table 1) due to higher values during periods of increased mixed layer depth (e.g. autumn turnover). Both of these measures of environmental light availability were 21 to $26 \%$ higher than the overall average physiological saturation intensity, $I_{k}$. $I_{k}$ was significantly correlated with both $\bar{I}_{Z_{\mathrm{p}^{\prime}}} \bar{I}_{Z_{\mathrm{ml}}{ }^{\prime}}$ as well as $\alpha^{B}$, but not with $P_{\mathrm{m}}^{B}$ (Table 4).

The positive correlation of $K$ with phytoplankton biomass for the entire data set (Table 4) was primarily attributable to high biomass periods during summer 


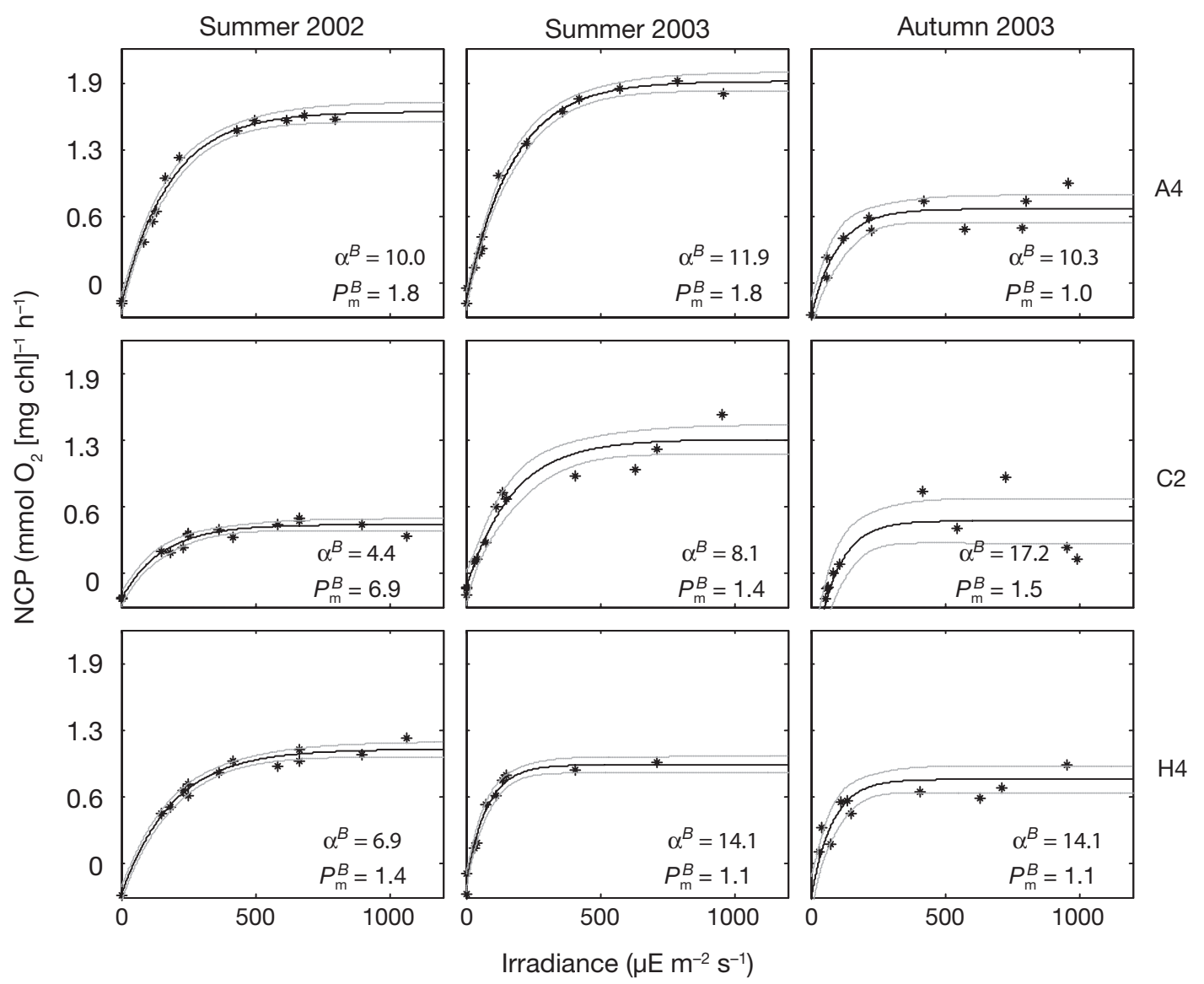

Fig. 4. Fitted $P-I$ curves and derived photosynthetic parameters $\left(\alpha^{B} ; \mu \mathrm{mol} \mathrm{O}_{2}[\mathrm{mg} \mathrm{chl}]^{-1} \mathrm{~h}^{-1}\left[\mu \mathrm{E} \mathrm{m} \mathrm{m}^{-2} \mathrm{~s}^{-1}\right]^{-1}\right.$ and $P_{\mathrm{m}}^{B}$; mmol $\mathrm{O}_{2}[\mathrm{mg}$ $\mathrm{chl}]^{-1} \mathrm{~h}^{-1}$ ) measured for surface-water samples collected at 3 stations along main axis of LIS (Stns A4, C2, and H4) during summers of 2002 and 2003, and autumn 2003. NCP: net community $\mathrm{O}_{2}$ production

$(\mathrm{r}=0.500, \mathrm{p}<0.001, \mathrm{n}=63)$ and spring $(\mathrm{r}=0.781, \mathrm{p}<$ $0.008, \mathrm{n}=9$ ). Note however, that chl on average only explains one quarter $\left(\mathrm{r}^{2}=0.26\right)$ of the variance in $K$ (Table 4).

$P-I$ parameters versus temperature. The relationship between $P_{\mathrm{m}}^{B}$ and temperature demonstrated considerable scatter (Fig. 8A). There is an upper envelope for variation in $P_{\mathrm{m}}^{B}$ with temperature, similar to that proposed for growth rate $(\mu)$ by Eppley (1972). However, the upper values here exceed the Eppley limit when $P_{\mathrm{m}}^{B}$ is converted to $\mu$ using $\mathrm{PQ}=1.2$ and adjusted for photoperiod. Similar disparities have been reported elsewhere (Brush et al. 2002).

\section{Community respiration rates $\left(R_{\mathrm{c}}\right)$}

In the upper mixed layer the volumetric rate of community respiration, $R_{\mathrm{C}}$ ranged from almost undetectable (0.06) to $4.0 \mathrm{mmol} \mathrm{O}_{2} \mathrm{~m}^{-3} \mathrm{~h}^{-1}$, with an average of $1.4 \pm 0.9 \mathrm{mmol} \mathrm{O}_{2} \mathrm{~m}^{-3} \mathrm{~h}^{-1}$ (Table 2). Although beyond the \pm 3 interquartile range criterion used to omit outliers, a replicated maximum respiration rate of $8.9 \mathrm{mmol} \mathrm{O}_{2} \mathrm{~m}^{-3} \mathrm{~h}^{-1}$ was observed. $R_{\mathrm{c}}$ demonstrated a significant gradient along the length of LIS in all seasons (Fig. 6, Table 2), with significantly higher rates at the head (western end) of the Sound in late July to early August of 2002 and 2003. $R_{\mathrm{C}}$ showed a weak nonlinear relationship with temperature (Fig. 8B).

The relationship between $R_{\mathrm{c}}$ and chl concentration sampled in surface waters was tested among individual sampling trips, individual sampled stations, and for the combined data set. The slopes of the relationship between $R_{\mathrm{C}}$ and chl were consistent for individual sampling trips (Fig. 9) and stations located along the main axis of the Sound, displaying no obvious temporal or spatial trends. However, one-quarter of these individual correlations did not exceed an $\mathrm{r}$ of 0.5 . These weak relationships between $R_{\mathrm{c}}$ and chl for individual sampling trips and stations are attributable to the low sample number (n) and small range of chl measured among these subsets. For the combined data set, a relationship between $R_{\mathrm{c}}$ and chl concentration in surface waters was highly significant $(r=0.60, p<0.001$, 


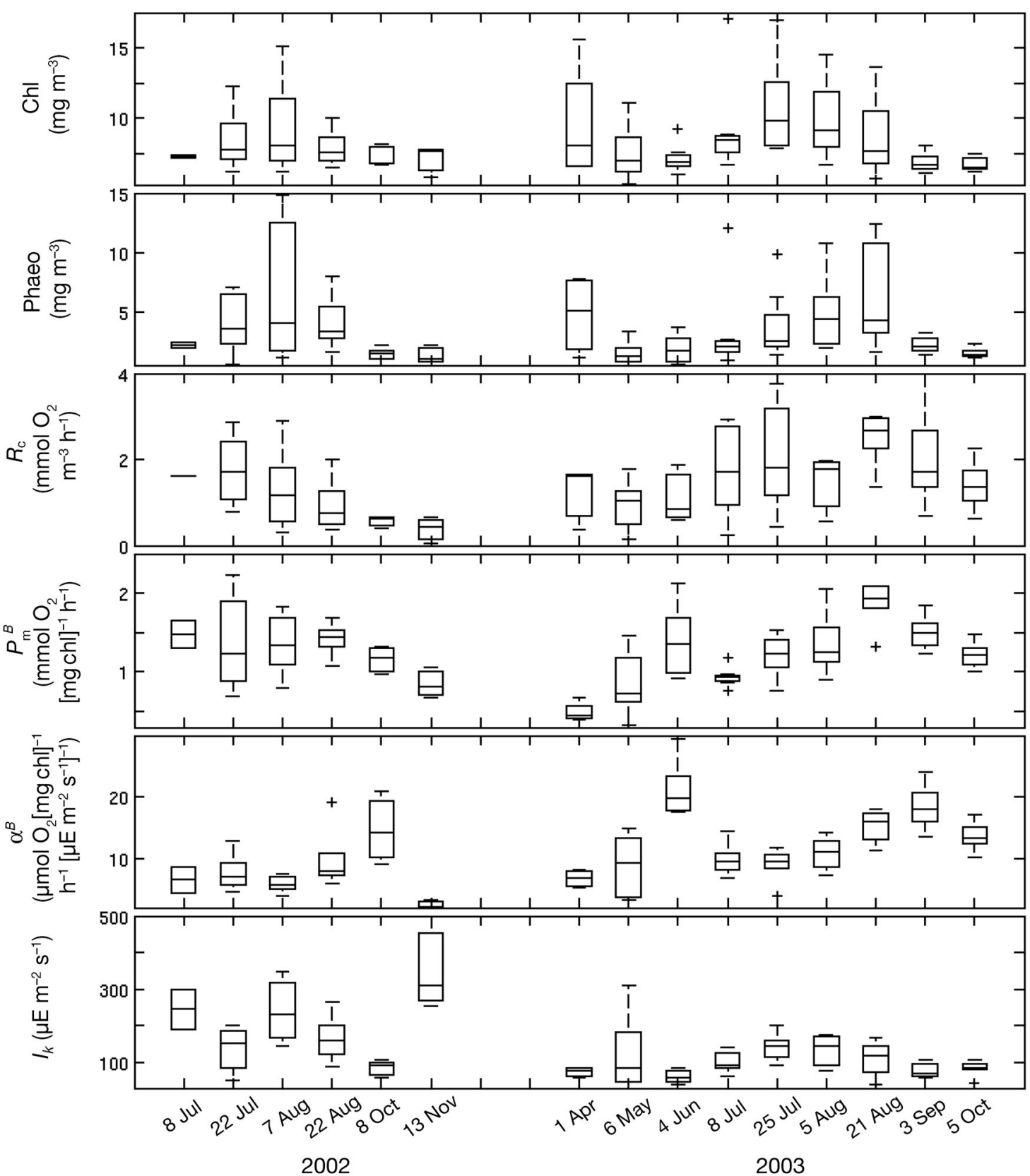

Fig. 5. Spatially averaged box-plots demonstrating seasonal variation in surface phytoplankton stock (chl), phaeopigments (phaeo), and photosynthetic parameters: $R_{\mathrm{c}}, P_{\mathrm{m}}^{B}, \alpha^{B}$ and $I_{\mathrm{k}}$ throughout summer and autumn of 2002 and spring, summer, and autumn of 2003. See Fig. 2 legend for further details

$\mathrm{n}=87$; Fig. 9). The overall slope of this relationship was $0.09 \pm 0.02 \mathrm{mmol} \mathrm{O}_{2}\left[\mathrm{mg} \mathrm{chl}^{-1} \mathrm{~h}^{-1}\right.$ with a $y$-intercept of $0.39 \pm 0.10 \mathrm{mmol} \mathrm{O}_{2} \mathrm{~m}^{-3} \mathrm{~h}^{-1}$.

The product of the slope of the above relationship and chl measured at each sampled station was used to estimate the daytime respiration associated with algae, $R_{\mathrm{a}}$. The mean and $95 \%$ confidence intervals for the ratio $R_{\mathrm{a}}: R_{\mathrm{C}}(0.51 \pm 0.08)$ suggests that chl was associated with about half of the measured daytime plankton community respiration in surface waters.

\section{Mid and bottom waters}

On average for all stations, concentrations of both chl and phaeo at mid depths were one-half of those measured at the surface, while chl and phaeo at bottom depths were one-third average surface values. Discrete measurements of chl at mid and bottom depths ranged from 2 to $180 \%$ of that measured at the surface, similar to the 7 to $100 \%$ observed at Stn A4 in LIS by Anderson \& Taylor (2001). At mid and bottom depths, 

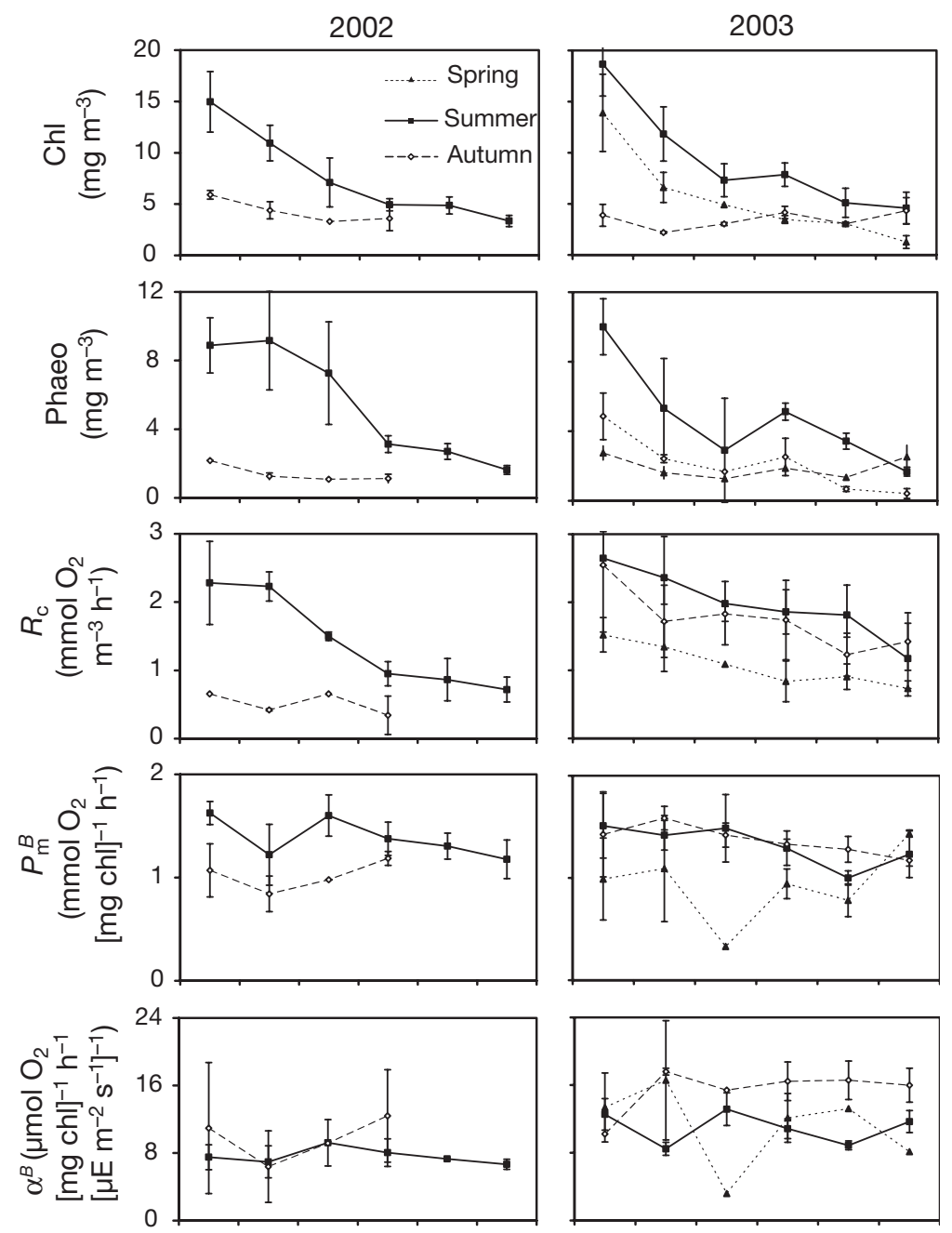

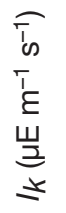

0

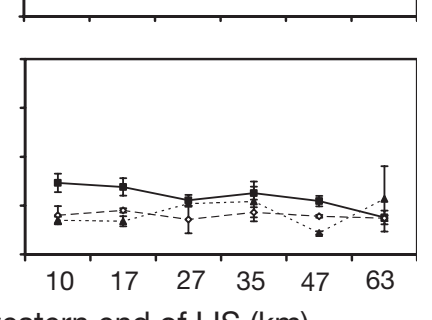

Distance from western end of LIS $(\mathrm{km})$

Fig. 6. Mean \pm SE interannual and spatial variation in surface phytoplankton stock: chl, phaeopigments: phaeo, community respiration: $R_{\mathrm{C}}$ and photosynthetic parameters: $P_{\mathrm{m}}^{B}, \alpha^{B}$ and $I_{\mathrm{k}}$ along main axis of central and western LIS averaged during summer and autumn of 2002 and spring, summer and autumn of 2003. Outliers ( $>3$ interquartile ranges) omitted

chl averaged $3.0 \pm 1.6$ and $1.7 \pm 1.0 \mathrm{mg} \mathrm{m}^{-3}$ and varied 19 - and 14 -fold over all samples, while phaeo averaged $2.3 \pm 1.1$ and $1.9 \pm 0.9 \mathrm{mg} \mathrm{m}^{-3}$ and varied 9 - and 15 -fold (Table 2). The phaeo:chl ratio increased with increasing depth, with averages of $0.9 \pm 0.6$ and $1.5 \pm 1.1$ and ranges of 10 - and 56-fold at mid and bottom depths, respectively (Table 2). Overall, both chl and phaeo at the surface were significantly correlated with their values measured in mid and bottom samples (Table 5).
Chl and phaeo were also significantly correlated at mid and bottom depths (Table 5). Chl and phaeo at mid and bottom depths demonstrated spatial gradients similar to those observed in surface waters.

$R_{\mathrm{C}}$ at mid and bottom depths of the water column ranged from undetectable to 2.8 and $1.9 \mathrm{mmol} \mathrm{O}_{2} \mathrm{~m}^{-3} \mathrm{~h}^{-1}$, with respective averages of $0.8 \pm 0.6$ and $0.7 \pm 0.5 \mathrm{mmol} \mathrm{O}_{2}$ $\mathrm{m}^{-3} \mathrm{~h}^{-1}$. These rates were typically less than half of that measured at the surface (Table 2). $R_{\mathrm{c}}$ at the surface was not correlated with $R_{\mathrm{C}}$ at mid or bottom depths over time or space. $R_{\mathrm{c}}$ at mid and bottom depths however, were significantly correlated (Table 5), attributable primarily to a highly significant relationship during summer. No obvious spatial gradients in $R_{\mathrm{c}}$ at mid and bottom depths were observed along the main axis of the Sound.

\section{DISCUSSION}

\section{Temporal and spatial variation in physiological parameters $\left(\alpha^{B}, P_{\mathrm{m}}^{B}, R_{\mathrm{c}}\right)$ and pigments}

Phytoplankton pigment concentrations and photosynthetic parameters demonstrated high variability in time (seasons) and space (along-Sound gradients) in LIS. The maxima in pigments, $P_{\mathrm{m}}^{B}$, and $R_{\mathrm{c}}$ at the head of the Sound during mid summer (Fig. 5) resulted in strong decreasing gradients of these variables and parameters along the main axis of LIS. The sustained, maximum summer chl $\left(24.1 \mathrm{mg} \mathrm{m}^{-3}\right.$; Table 2) was comparable to that measured by Riley $\left(1959 ; \sim 23 \mathrm{mg} \mathrm{m}^{-3}\right.$ ) and Anderson \& Taylor $\left(2001 ; 28.2 \mathrm{mg} \mathrm{m}^{-3}\right)$, all measured in the western end of LIS during the summer. Our average chl in LIS compares well with the annual average chl measured in surface waters of other eutrophic systems such as mid-Chesapeake Bay (Harding et al. 2002), upper Narragansett Bay (Oviatt et al. 2002) and Suisun Bay channel of San Francisco Bay (Cole \& Cloern 1984). We did not sample during the winterspring season, suggesting that a more complete annual average for LIS might be even higher with the inclusion of non-sampled winter bloom values.

Maximum estimates of $P_{\mathrm{m}}^{B}$ and $\alpha^{B}$ in LIS, converted to units of carbon for comparison with ${ }^{14} \mathrm{C}$, are 1.5 and 3 times the maximum measured in some other produc- 
tive systems such as the Chesapeake and Delaware Bays (Harding et al. 1985, 1986). Converted maxima of $P_{\mathrm{m}}^{B}$ measured in LIS $\left(\sim 2.1 \mathrm{mmol} \mathrm{C}[\mathrm{mg} \mathrm{chl}]^{-1} \mathrm{~h}^{-1}\right)$ matched the theoretical maximum $(2.1 \mathrm{mmol} \mathrm{C}[\mathrm{mg}$ $\mathrm{chl}^{-1} \mathrm{~h}^{-1}$ ) calculated by Falkowski (1981). However converted maxima of $\alpha^{B}\left(\sim 0.02 \mathrm{mmol} \mathrm{C}\left[\mathrm{mg} \mathrm{chl}^{-1} \mathrm{~h}^{-1}\right.\right.$

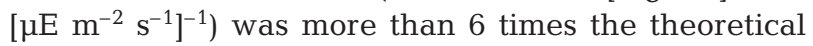
maximum (0.003 mmol C $\left[\mathrm{mg} \mathrm{chl}^{-1} \mathrm{~h}^{-1}\left[\mu \mathrm{E} \mathrm{m} \mathrm{m}^{-2} \mathrm{~s}^{-1}\right]^{-1}\right)$ calculated by Platt \& Jassby (1976), even after removal of weakly fitted $P-I$ curves and exclusion of out-

Table 4. Bivariate Pearson correlation coefficients for $P-I$ parameters, community respiration, surface temperature $(T)$ and chlorophyll (chl), average chlorophyll in the euphotic zone ( $\left(\mathrm{chl}_{\mathrm{avg}}\right)$, and irradiance variables $\left(K, Z_{\mathrm{p}}, Z_{\mathrm{ml}}, \bar{I}_{Z_{\mathrm{ml}}}\right.$ and $\left.\bar{I}_{Z_{\mathrm{p}}}\right)$. Correlation coefficient (r), significance (p), and number of samples (n) are shown. Correlations in boldface are significant at $\mathrm{p}<0.05$ level (2-tailed). Outliers omitted

\begin{tabular}{|c|c|c|c|c|c|c|c|c|c|c|c|c|}
\hline & $\alpha^{B}$ & $P_{\mathrm{m}}^{B}$ & $I_{\mathrm{k}}$ & $R_{\mathrm{c}}$ & $T$ & Chl & $\mathrm{Chl}_{\mathrm{avg}}$ & $K$ & $Z_{\mathrm{p}}$ & $Z_{\mathrm{ml}}$ & $\bar{I}_{Z_{\mathrm{ml}}}$ & $\bar{I}_{Z_{\mathrm{p}}}$ \\
\hline \multicolumn{13}{|l|}{$P_{\mathrm{m}}^{B}$} \\
\hline $\mathrm{r}$ & 0.380 & & & & & & & & & & & \\
\hline $\mathrm{p}$ & $<0.001$ & & & & & & & & & & & \\
\hline $\mathrm{n}$ & 90 & & & & & & & & & & & \\
\hline \multicolumn{13}{|l|}{$I_{\mathrm{k}}$} \\
\hline $\mathrm{r}$ & -0.650 & 0.143 & & & & & & & & & & \\
\hline $\mathrm{p}$ & $<0.001$ & 0.167 & & & & & & & & & & \\
\hline $\mathrm{n}$ & 90 & 95 & & & & & & & & & & \\
\hline \multicolumn{13}{|l|}{$R_{\mathrm{C}}$} \\
\hline$r$ & 0.071 & 0.287 & -0.083 & & & & & & & & & \\
\hline $\mathrm{p}$ & 0.527 & 0.007 & 0.446 & & & & & & & & & \\
\hline $\mathrm{n}$ & 82 & 87 & 87 & & & & & & & & & \\
\hline \multicolumn{13}{|l|}{$T$} \\
\hline $\mathrm{r}$ & 0.042 & 0.518 & 0.217 & 0.305 & & & & & & & & \\
\hline $\mathrm{p}$ & 0.692 & $<0.001$ & 0.033 & 0.004 & & & & & & & & \\
\hline $\mathrm{n}$ & 91 & 96 & 97 & 88 & & & & & & & & \\
\hline \multicolumn{13}{|l|}{ Chl } \\
\hline $\mathrm{r}$ & -0.171 & 0.058 & 0.279 & 0.463 & 0.164 & & & & & & & \\
\hline $\mathrm{p}$ & 0.104 & 0.573 & 0.006 & $<0.001$ & 0.106 & & & & & & & \\
\hline $\mathrm{n}$ & 91 & 96 & 97 & 88 & 98 & & & & & & & \\
\hline \multicolumn{13}{|c|}{$\mathrm{Chl}_{\mathrm{avg}}$} \\
\hline $\mathrm{r}$ & -0.263 & -0.090 & 0.251 & 0.406 & 0.100 & 0.894 & & & & & & \\
\hline $\mathrm{p}$ & 0.012 & 0.381 & 0.013 & $<0.001$ & 0.328 & $<0.001$ & & & & & & \\
\hline $\mathrm{n}$ & 91 & 96 & 97 & 88 & 98 & 98 & & & & & & \\
\hline \multicolumn{13}{|l|}{$K$} \\
\hline $\mathrm{r}$ & 0.177 & 0.254 & 0.085 & 0.206 & 0.127 & 0.515 & 0.450 & & & & & \\
\hline $\mathrm{p}$ & 0.094 & 0.013 & 0.408 & 0.054 & 0.212 & $<0.001$ & $<0.001$ & & & & & \\
\hline $\mathrm{n}$ & 91 & 96 & 97 & 88 & 98 & 98 & 98 & & & & & \\
\hline \multicolumn{13}{|l|}{$Z_{\mathrm{p}}$} \\
\hline $\mathrm{r}$ & -0.067 & -0.235 & -0.111 & -0.231 & -0.218 & -0.485 & -0.434 & -0.876 & & & & \\
\hline $\mathrm{p}$ & 0.528 & 0.021 & 0.281 & 0.030 & 0.031 & $<0.001$ & $<0.001$ & $<0.001$ & & & & \\
\hline $\mathrm{n}$ & 91 & 96 & 97 & 88 & 98 & 98 & 98 & 98 & & & & \\
\hline \multicolumn{13}{|l|}{$Z_{\mathrm{ml}}$} \\
\hline $\mathrm{r}$ & 0.282 & 0.104 & -0.256 & -0.096 & -0.018 & -0.325 & -0.360 & -0.229 & 0.242 & & & \\
\hline $\mathrm{p}$ & 0.007 & 0.315 & 0.011 & 0.375 & 0.858 & $<0.001$ & $<0.001$ & 0.023 & 0.016 & & & \\
\hline $\mathrm{n}$ & 91 & 96 & 97 & 88 & 98 & 98 & 98 & 98 & 98 & & & \\
\hline \multicolumn{13}{|l|}{$\bar{I}_{Z_{\mathrm{ml}}}$} \\
\hline $\mathrm{r}$ & -0.345 & 0.046 & 0.301 & 0.284 & 0.238 & 0.378 & 0.378 & -0.079 & -0.038 & -0.517 & & \\
\hline $\mathrm{p}$ & $<0.001$ & 0.656 & 0.003 & 0.007 & 0.018 & $<0.001$ & $<0.001$ & 0.440 & 0.713 & $<0.001$ & & \\
\hline $\mathrm{n}$ & 91 & 96 & 97 & 88 & 98 & 98 & 98 & 98 & 98 & 98 & & \\
\hline \multicolumn{13}{|l|}{$\bar{I}_{Z_{\mathrm{p}}}$} \\
\hline $\mathrm{r}$ & -0.278 & 0.326 & 0.371 & 0.380 & 0.487 & 0.341 & 0.324 & -0.011 & -0.108 & -0.076 & -0.637 & \\
\hline $\mathrm{p}$ & 0.008 & $<0.001$ & $<0.001$ & $<0.001$ & $<0.001$ & $<0.001$ & $<0.001$ & 0.916 & 0.291 & 0.456 & $<0.001$ & \\
\hline $\mathrm{n}$ & 91 & 96 & 97 & 88 & 98 & 98 & 98 & 98 & 98 & 98 & 98 & \\
\hline \multicolumn{13}{|l|}{$I_{0}$} \\
\hline $\mathrm{r}$ & -0.284 & 0.334 & 0.393 & 0.399 & 0.526 & 0.362 & 0.343 & 0.072 & -0.109 & -0.190 & 0.654 & 0.949 \\
\hline $\mathrm{p}$ & 0.006 & $<0.001$ & $<0.001$ & $<0.001$ & $<0.001$ & $<0.001$ & $<0.001$ & 0.483 & 0.285 & 0.061 & $<0.001$ & $<0.001$ \\
\hline $\mathrm{n}$ & 91 & 96 & 97 & 88 & 98 & 98 & 98 & 98 & 98 & 98 & 98 & 98 \\
\hline
\end{tabular}


Table 5. Bivariate Pearson correlation coefficients for chlorophyll (chl) and phaeopigment (phaeo) concentrations, and rates of community respiration $\left(R_{\mathrm{c}}\right)$ in samples collected from the surface, mid and bottom depths. Subscripts designate surface $(\mathrm{s})$, mid $(\mathrm{m})$ and bottom $(\mathrm{b})$ sample depths. Correlation coefficients $(\mathrm{r})$, significance $(\mathrm{p})$ and number of samples (n) are shown. Correlations in boldface are significant at $\mathrm{p}<0.01$ level (2-tailed). Outliers omitted

\begin{tabular}{|c|c|c|c|c|c|c|c|c|}
\hline & $\mathrm{Chl}_{\mathrm{s}}$ & $\mathrm{Phaeo}_{\mathrm{s}}$ & $R_{\mathrm{C}_{\mathrm{s}}}$ & $\mathrm{Chl}_{\mathrm{m}}$ & $\mathrm{Phaeo}_{\mathrm{m}}$ & $R_{\mathrm{C}_{\mathrm{m}}}$ & $\mathrm{Chl}_{\mathrm{b}}$ & $\mathrm{Phaeo}_{\mathrm{b}}$ \\
\hline \multicolumn{9}{|l|}{$\mathrm{Phaeo}_{\mathrm{s}}$} \\
\hline $\mathrm{r}$ & 0.728 & & & & & & & \\
\hline $\mathrm{p}$ & $<0.001$ & & & & & & & \\
\hline $\mathrm{n}$ & 98 & & & & & & & \\
\hline \multicolumn{9}{|l|}{$R_{\mathrm{C}_{\mathrm{S}}}$} \\
\hline $\mathrm{r}$ & 0.463 & 0.444 & & & & & & \\
\hline $\mathrm{p}$ & $<0.001$ & $<0.001$ & & & & & & \\
\hline $\mathrm{n}$ & 88 & 88 & & & & & & \\
\hline \multicolumn{9}{|l|}{$\mathrm{Chl}_{\mathrm{m}}$} \\
\hline $\mathrm{r}$ & 0.562 & 0.290 & 0.196 & & & & & \\
\hline $\mathrm{p}$ & $<0.001$ & 0.004 & 0.067 & & & & & \\
\hline $\mathrm{n}$ & 98 & 98 & 88 & & & & & \\
\hline \multicolumn{9}{|l|}{$\mathrm{Phaeo}_{\mathrm{m}}$} \\
\hline $\mathrm{r}$ & 0.514 & 0.550 & 0.287 & 0.546 & & & & \\
\hline $\mathrm{p}$ & $<0.001$ & $<0.001$ & 0.007 & $<0.001$ & & & & \\
\hline $\mathrm{n}$ & 98 & 98 & 88 & 98 & & & & \\
\hline \multicolumn{9}{|l|}{$R_{\mathrm{c}_{\mathrm{m}}}$} \\
\hline $\mathrm{r}$ & 0.158 & 0.222 & 0.175 & 0.026 & 0.130 & & & \\
\hline $\mathrm{p}$ & 0.172 & 0.053 & 0.154 & 0.821 & 0.261 & & & \\
\hline $\mathrm{n}$ & 76 & 76 & 68 & 76 & 76 & & & \\
\hline \multicolumn{9}{|l|}{$\mathrm{Chl}_{\mathrm{b}}$} \\
\hline $\mathrm{r}$ & 0.339 & 0.167 & -0.013 & 0.755 & 0.318 & 0.138 & & \\
\hline $\mathrm{p}$ & $<0.001$ & 0.101 & 0.902 & $<0.001$ & $<0.001$ & 0.233 & & \\
\hline $\mathrm{n}$ & 98 & 98 & 88 & 98 & 98 & 76 & & \\
\hline \multicolumn{9}{|l|}{$\mathrm{Phaeo}_{\mathrm{b}}$} \\
\hline $\mathrm{r}$ & 0.336 & 0.182 & 0.035 & 0.477 & 0.450 & 0.001 & 0.666 & \\
\hline $\mathrm{p}$ & $<0.001$ & 0.074 & 0.747 & $<0.001$ & $<0.001$ & 0.996 & $<0.001$ & \\
\hline $\mathrm{n}$ & 97 & 97 & 87 & 97 & 97 & 75 & 97 & \\
\hline \multicolumn{9}{|l|}{$R_{\mathrm{C}_{\mathrm{b}}}$} \\
\hline $\mathrm{r}$ & -0.071 & 0.062 & 0.047 & 0.008 & 0.122 & 0.484 & 0.302 & 0.346 \\
\hline $\mathrm{p}$ & 0.542 & 0.596 & 0.702 & 0.946 & 0.295 & $<0.001$ & 0.008 & 0.002 \\
\hline $\mathrm{n}$ & 76 & 76 & 69 & 76 & 76 & 62 & 76 & 75 \\
\hline
\end{tabular}

liers (see 'Materials and methods'). The mean of $\alpha^{B}$ (0.009 mmol C $[\mathrm{mg} \mathrm{chl}]^{-1} \mathrm{~h}^{-1}\left[\mu \mathrm{E} \mathrm{m} \mathrm{m}^{-2} \mathrm{~s}^{-1}\right]^{-1}$ ) was within the same order of magnitude as theory, but still higher. High measurements of $\alpha^{B}$ have also been observed in other studies (Platt \& Jassby 1976, Malone \& Neale 1981, Kelly \& Doering 1997).

Seasonality in $\alpha^{B}$ was not as distinct as $P_{\mathrm{m}}^{B} ; \alpha^{B}$ increased during each summer and was significantly higher in 2003, but lacked any defined spatial and temporal trends like those of $P_{\mathrm{m}}^{B}$ and chl (Figs. $5 \& 7$ ). Although variability of $\alpha^{B}$ in LIS during summers decreased (i.e. 5- to 8-fold ranges versus 14 -fold overall; Table 1), $\alpha^{B}$ variability was still at least double that of $P_{\mathrm{m}}^{B}$ during individual seasons as well as over the duration of the study (Table 1). Higher variability in $\alpha^{B}$ contrasts with that reported in diel (MacCaull \& Platt 1977, Prézelin \& Sweeney 1977), daily (Cote \& Platt 1983) and seasonal (Platt \& Jassby 1976) P-I studies, where range factors of $\alpha^{B}$ were similar to or less than $P_{\mathrm{m}}^{B}$. In those studies, however, $P-I$ parameters did not necessarily correlate temporally, as was observed in the present study. Relatively high variability in the fit of $\alpha^{B}$ is not unusual. Aalderink \& Jovin (1997) measured similar disparities in the fit of $P-I$ parameters across 8 model types for oxygen production and consumption in light and dark bottle incubations, whether these parameters were fitted using net or gross rates of primary production. Higher variability in the fit of $P-I$ parameters does not appear to result from use of the $\mathrm{O}_{2}$ method. This was demonstrated by similar variability in the curve-fits of our $P-I$ parameters to that calculated using both $\mathrm{O}_{2}$ and ${ }^{14} \mathrm{C}$ in Massachusetts Bay (Kelly \& Doering 1997). Importantly, Kelly \& Doering (1997) demonstrated that imprecise measures of $\alpha^{B}$ do not largely influence calculations of integrated production, yet Aalderink \& Jovin (1997) stressed the impor- 

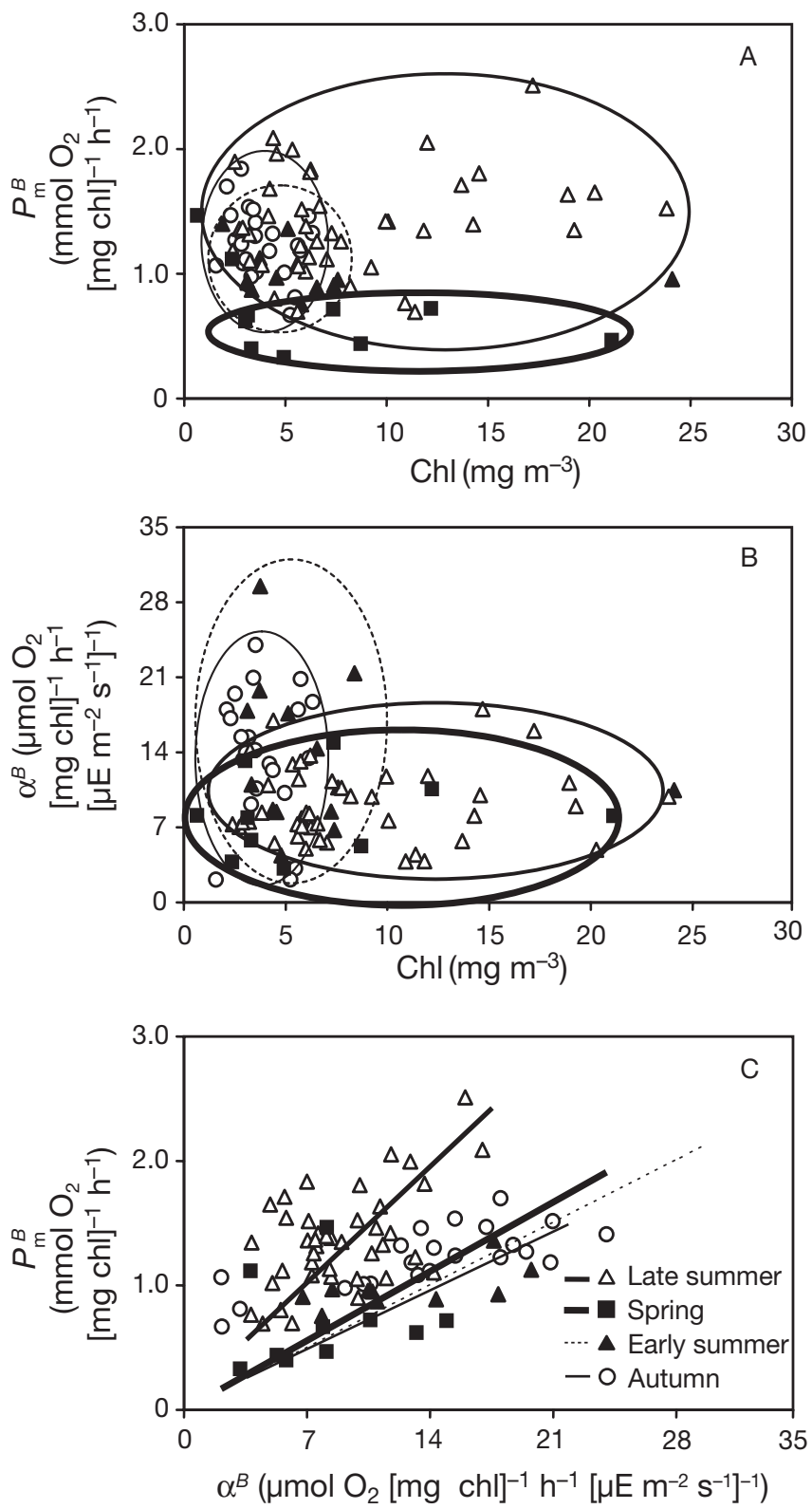

Fig. 7. Seasonal relationships between (A) maximum photosynthetic rate $\left(P_{\mathrm{m}}^{B}\right)$ and chl, (B) photosynthetic efficiency $\left(\alpha^{B}\right)$ and chl, and (C) $P_{\mathrm{m}}^{B}$ and $\alpha^{B}$ for all sample data. Both sample years combined and reported by season, which are indicated by ellipses containing seasonal clusters of data in (A) and (B), and by regression lines for each season in (C). Overlapping ellipses in (A) distinguish similarities in relationship between $P_{\mathrm{m}}^{B}$ and chl during low chl periods of autumn (thin line) and early summer (dotted line), from high chl-high $P_{\mathrm{m}}^{B}$ during late summer (medium line) and high chl-low $P_{\mathrm{m}}^{B}$ during spring (dark line). Pairs of overlapping ellipses in (B) indicate fewer seasonal differences in relationship between $\alpha^{B}$ and chl during low chl periods (autumn and early summer) and high chl periods (late summer and spring). Seasonal variations in relationship between $\alpha^{B}$ and $P_{\mathrm{m}}^{B}$ are demonstrated by regression lines for each season in $(C)$, where highest slope was in late summer $(\mathrm{r}=0.54)$, decreasing to spring $(\mathrm{r}=0.84)$, early summer $(r=0.50)$, and autumn (lowest slope, $r=0.75)$. Outliers omitted
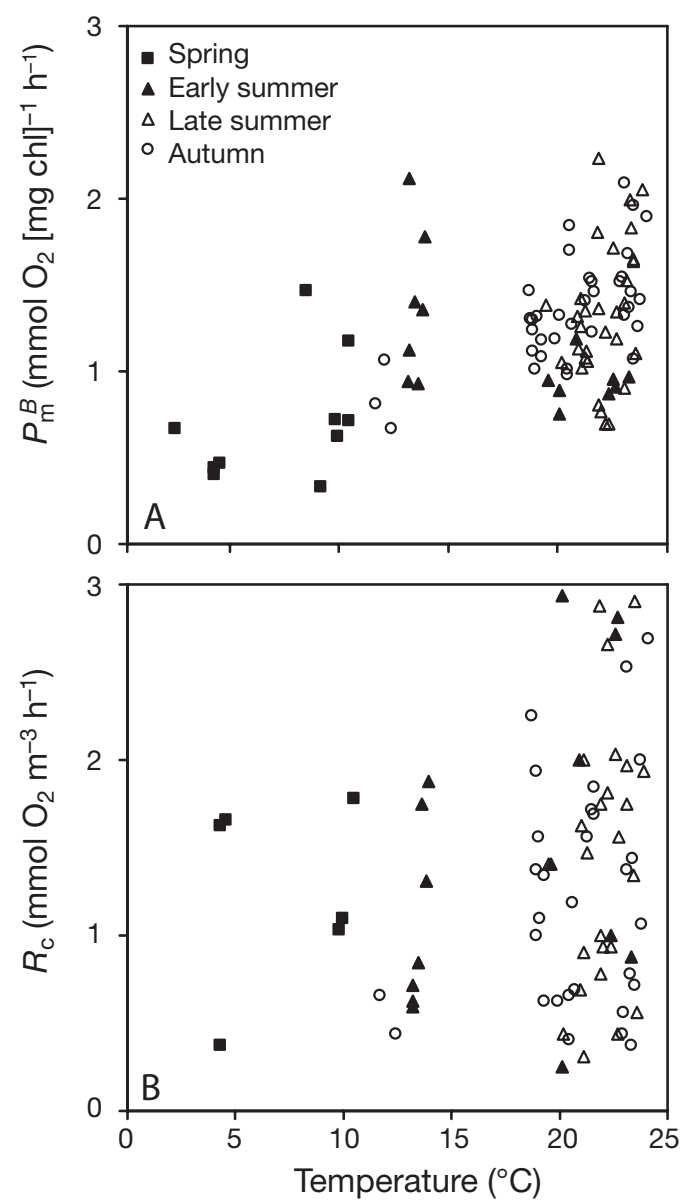

Fig. 8. Temperature versus (A) maximum photosynthetic rate $\left(P_{\mathrm{m}}^{B}\right)$ and $(\mathrm{B})$ community respiration $\left(R_{\mathrm{c}}\right)$ for all sample data. Outliers omitted

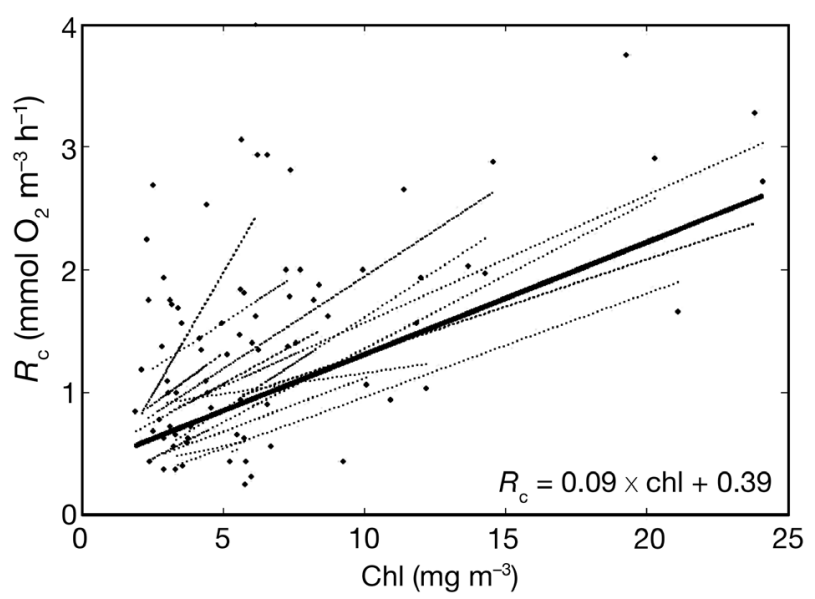

Fig. 9. Relationship between community respiration $\left(R_{\mathrm{c}}\right)$ and chlorophyll (chl) concentration of surface-water samples measured on each sampling trip (dotted lines) and for all data (continuous line). Overall slope calculated in weighted Model II regression was $0.09 \pm 0.02 \mathrm{mmol} \mathrm{O}_{2}[\mathrm{mg} \mathrm{chl}]^{-1} \mathrm{~h}^{-1}$ with an intercept of $0.39 \pm 0.10 \mathrm{mmol} \mathrm{O}_{2} \mathrm{~m}^{-3} \mathrm{~h}^{-1}(\mathrm{r}=0.60, \mathrm{p}<$ $0.001, \mathrm{n}=87$ ). Slopes for most individual sampling trips were similar to overall slope, although not all were significant 
tance of precise parameter estimation when investigating their individual dependencies on environmental conditions.

The average $R_{\mathrm{c}}$ in LIS for all seasons and stations (1.4 $\mathrm{mmol} \mathrm{O}_{2} \mathrm{~m}^{-3} \mathrm{~h}^{-1}$ ) was more than twice the maximum rates measured in surface waters of western LIS by Riley (1959), although his method employed 3 to $4 \mathrm{~d}$ dark incubations. Our results compared favorably to more recent studies in LIS. The maximum $24 \mathrm{~h}$ dark incubation measured in surface waters at the head of LIS by Anderson \& Taylor (2001) was equivalent to $2.1 \mathrm{mmol} \mathrm{O}_{2} \mathrm{~m}^{-3} \mathrm{~h}^{-1}$. The average for $8 \mathrm{~h}$ incubations in surface waters throughout central and western LIS by Welsh \& Eller (1991) was $\sim 1.9 \mathrm{mmol} \mathrm{O}_{2} \mathrm{~m}^{-3} \mathrm{~h}^{-1}$. Our results also compare well with those of other eutrophic systems, such as the average measured during spring to autumn at the head of a eutrophic Danish estuary (1.8 $\mathrm{mmol} \mathrm{O}_{2} \mathrm{~m}^{-3} \mathrm{~h}^{-1}$; Jensen et al. 1990). The overall average rate for LIS is $\sim 3$ times the global geometric mean $\left(9.1 \mathrm{mmol} \mathrm{C} \mathrm{m} \mathrm{m}^{-3} \mathrm{~d}^{-1} ; \mathrm{n} \approx 700\right.$ ) and 1.6 times the arithmetic mean $\left(17.8 \mathrm{mmol} \mathrm{C} \mathrm{m}{ }^{-3} \mathrm{~d}^{-1}\right)$ for 21 estuarine systems (Hopkinson \& Smith 2005, p. 133, 134). The maximum rate of respiration measured in the present study $\left(8.9 \mathrm{mmol} \mathrm{O}_{2} \mathrm{~m}^{-3} \mathrm{~h}^{-1}\right)$ is among the highest reported, equating to 25 and 12 times these global geometric and arithmetic means.

Numerous ecological factors may contribute real variation in the parameters, such as mean cell size (Platt \& Jassby 1976), nutrient availability (Lohrenz et al. 1993), changes in community structure associated with episodic physical events and growth conditions (Cote \& Platt 1983, Forbes et al. 1987, Macedo et al. 2001), variation in the quantum yield and light trapping capacity of the resident phytoplankton community (Sosik \& Mitchell 1995), or shifts in the fraction of photosynthetically produced reductants allocated to carbon fixation (Behrenfeld et al. 2004). Contribution of these factors as sources of variability in $P-I$ parameters is not within the scope of the present study. We are able however, to explore the relationship between the variability of photosynthetic parameters, pigments, light and physics in the water column.

\section{Relationships among photosynthetic parameters, pigments, light and water-column physics}

Seasonal variability in chl and $P-I$ parameters presumably result from varied responses of the phytoplankton community to changing conditions of temperature, light, water column structure and nutrients. Our data include a number of relevant descriptors of the photosynthetic environment: incident irradiance $\left(I_{0}\right)$, light attenuation $(K)$, and depth and average irradiance of the photic zone $\left(Z_{\mathrm{p}}, \bar{I}_{Z_{\mathrm{p}}}\right)$, and of the mixed layer $\left(Z_{\mathrm{ml}}, \bar{I}_{Z_{\mathrm{ml}}}\right)$. The covariance of chl, $P_{\mathrm{m}}^{B}$ and $\alpha^{B}$ with all or several of these descriptors (Table 4) affirms and quantifies the obvious importance of light in determining chl and photosynthesis in LIS. Summer increases in chl with $I_{0}$ and stratification (as $Z_{\mathrm{ml}}$ ) were also seen at Stn A4 by Anderson \& Taylor (2001) during 1992 and 1993.

$P_{\mathrm{m}}^{B}$ covaried with both $T_{\mathrm{s}}$ and $I_{0}$. It was not possible however, to distinguish between the importance of $I_{0}$ and $T_{\mathrm{s}}$ in the prediction of $P_{\mathrm{m}}^{B}$, since day-to-day variability in both obscured any seasonal offset. Significant relationships between $P_{\mathrm{m}}^{B}$ and $T$ were also found by Cote \& Platt (1983), Behrenfeld \& Falkowski (1997) and Macedo et al. (2001). In contrast, Gaxiola-Castro et al. (1999) did not observe a relationship between $P_{\mathrm{m}}^{B}$ and $T$, or nutrient concentrations. They did report a non-linear relationship between $P_{\mathrm{m}}^{B}$ and stratification of the water column, implying complex interactions of $P_{\mathrm{m}}^{B}$ with light, nutrients and water-column structure. Despite observed relationships between $P_{\mathrm{m}}^{B}$ and $T$, Cote \& Platt (1983), Cullen et al. (1992) and Behrenfeld \& Falkowski (1997) emphasized that factors other than temperature are responsible for variability in $P_{\mathrm{m}}^{B}$, such as light acclimation. The scatter in our relationship of $P_{\mathrm{m}}^{B}$ to $T$ in LIS (Fig. 8) suggests that temperature may not promote blooms directly (i.e. physiologically), but rather may play a more important role via increased stratification of the water column. Furthermore, our calculations of growth rate based on $P_{\mathrm{m}}^{B}$ offer another example of productivity data that exceed the Eppley temperature curve (Brush et al. 2002). Clearly, the Eppley temperature-dependent growth model is not an accurate predictor of maximum phytoplankton photosynthesis in LIS.

Both Riley (1959) and Anderson \& Taylor (2001) stressed the importance of stratification and increased light availability to the progression of the summer to autumn period of increased productivity in LIS. As pointed out by Anderson \& Taylor (2001), the variation in underwater irradiance is controlled more by $I_{0}$ than water clarity, $K$. This importance of $I_{0}$ is supported by increases in $P_{\mathrm{m}}^{B}$ and chl during the summer, despite increased self-shading indicated by parallel increases in phytoplankton biomass and $K$ along the axis of LIS.

Unlike $P_{\mathrm{m}}^{B}, \alpha^{B}$ was not correlated with temperature, but as expected $\alpha^{B}$ was inversely correlated with depth and light availability of the mixed layer $\left(Z_{\mathrm{ml}}\right.$ and $\left.\bar{I}_{Z_{\mathrm{ml}}}\right)$. This suggests that variability in $\alpha^{B}$ may be associated with adaptation of phytoplankton communities to significant changes in the light regime associated with the structure of the water column. The dependence of $\alpha^{B}$ on light levels and efficiency of light harvesting by resident phytoplankton communities of LIS is discussed using the derived parameter $I_{\mathrm{k}}$. 
$I_{\mathrm{k}}\left(=P_{\mathrm{m}}^{B}: \alpha^{B}\right)$ characterizes physiological adaptations to the environment (Beardall \& Morris 1976) and growth potential (Prézelin \& Matlick 1980) of algal populations. Average $I_{\mathrm{k}}$ in LIS $\left(132 \pm 72 \mu \mathrm{E} \mathrm{m} \mathrm{m}^{-2} \mathrm{~s}^{-1}\right)$ was similar to values measured in other coastal regions of relatively shallow mixed layers, such as the range and average measured in Chesapeake and Delaware Bays (Harding et al. 1986). The relatively high values of $I_{\mathrm{k}}$ in LIS indicate that phytoplankton communities were adapted to high irradiances (i.e. light-adapted), according to the criteria of Steeman Nielsen \& Hansen (1959) and Ichimura (1960).

Comparison of $I_{\mathrm{k}}$ with the amount of available in situ irradiance $\left(\bar{I}_{Z_{\mathrm{ml}}}\right)$ has been used to indicate how phytoplankton communities adapt to variations of irradiance in a hydrographically variable water column (Figueiras et al. 1994, 1998). Typically, $I_{\mathrm{k}}$ is expected to decrease with high chl (i.e. decreased light availability due to self-shading should lead to lower $I_{\mathrm{k}}$ through shade adaptation). Yet, in LIS, $I_{\mathrm{k}}$ increased with increasing chl and $I_{0}$ during peaks in productivity, and covaried with $K$ along the length of LIS. Mean irradiance levels in the photic zone $\left(\bar{I}_{Z_{\mathrm{p}}}\right)$ and the mixed layer $\left(\bar{I}_{Z_{\mathrm{ml}}}\right)$ were only 21 and $26 \%$ higher than average $I_{\mathrm{k}}$. The agreement between available light and $I_{\mathrm{k}}$ despite relatively high light attenuation suggests that LIS phytoplankton are not limited (nor photoinhibited) by light, and hence may be effectively adapted to their light regime much of the time, perhaps even for maximal rates of productivity.

We tested for seasonal variability in $I_{\mathrm{k}}$ utilizing the overall significant relationship between observations of $P_{\mathrm{m}}^{B}$ and $\alpha^{B}$ compiled for spring, early and late summer, and autumn seasons. The slope of the regression of $P_{\mathrm{m}}^{B}$ to $\alpha^{B}$ (Fig. $7 \mathrm{C}$ ), did not differ significantly among spring, early summer and autumn, but increased 2-fold during late summer of both sampled years. This increase in $I_{\mathrm{k}}$ during late summer results from the asymmetries in the relationships of these $P-I$ parameters to $\mathrm{chl}$, whereby $P_{\mathrm{m}}^{B}$ increased more rapidly during late summer in relation to both chl and $\alpha^{B}$ (Figs. 7A, B).

Nutrients have not been included in this paper. Strong gradients in surface chl and $P_{\mathrm{m}}^{B}$ that decrease with increasing distance from the western end of LIS may implicate the influence of nutrients as well as salinity and temperature structure. In addition to higher stratification, nutrients in the waters at the head of LIS promote high productivity and chl in surface waters. Riley (1959) reports similar spatial gradients in chl and nutrients for inner, mid and outer regions of LIS. Additionally, seasonal blooms were accompanied by decreases in inorganic forms of nitrogen and phosphorus during present (CTDEP data, not shown) and previous studies (Riley 1959, Anderson \& Taylor 2001), indicating uptake of available nutrients by phytoplankton. Al- though nutrients were undetectable during peak concentrations of chl, the breakdown in stratification with storms in September of 2002 and 2003 promptly replenished surface nutrient (and bottom-water oxygen) concentrations (CTDEP data, not shown), as was also observed by Anderson \& Taylor (2001).

\section{Respiration}

Surface waters

The rate of plankton-community respiration $\left(R_{\mathrm{C}}\right)$ measured in the surface mixed layer of LIS correlated significantly with chl and $P_{\mathrm{m}}^{B}$ (Table 4, Fig. 9), particularly during summer at the western end of the Sound. Chl explained more than twice as much variance in $R_{\mathrm{C}}$ than in $P_{\mathrm{m}}^{B}$. We used the slope of the regression of $R_{\mathrm{C}}$ on chl to estimate a rate of daytime 'algal-related' respiration, $R_{\mathrm{a}}$ (i.e. algal respiration and microbial respiration associated with algal exudates). The $y$-intercept is a constant that represents respiration not associated with chl, or non-algal-related respiration (e.g. heterotrophic oxidation of detrital material), also referred to as non-phytoplankton or background respiration by Cohen (1990) and Jensen et al. (1990).

The overall slope of the relationship between $R_{\mathrm{C}}$ and chl was $0.09 \pm 0.02 \mathrm{mmol} \mathrm{O}_{2}[\mathrm{mg} \mathrm{chl}]^{-1} \mathrm{~h}^{-1}$, where chl explained $37 \%$ of the variation in $R_{\mathrm{c}}$ (Fig. 9). This overall relationship did not differ significantly from the average for relationships tested across individual sampling trips and stations. The correlation between $R_{\mathrm{C}}$ and chl for the most eutrophic station at the western end of the Sound (A4) was especially strong and had the same slope $\left(0.09 \pm 0.03 \mathrm{mmol} \mathrm{O}_{2}[\mathrm{mg} \mathrm{chl}]^{-1} \mathrm{~h}^{-1} ; \mathrm{r}=\right.$ $0.83)$. This region is likely to receive higher inputs of allochthonous dissolved organic carbon, which might fuel increased rates of non-algal respiration. However, the $R_{\mathrm{c}}$ versus chl slope at this station was consistent with the overall slope, and with the slopes of most individual sampling trips. Further, no temporal or spatial trends were observed in this relationship, although low sample numbers and small ranges of chl observed during individual trips and at individual stations meant that these regressions were not all significant. Therefore we estimate $R_{\mathrm{a}}$ for all stations using the slope of the combined regression.

The average of $R_{\mathrm{a}}$ as a fraction of observed $R_{\mathrm{C}}$ indicated that algal-related respiration constitutes 43 to $60 \%$ of daytime community respiration. Our estimates of the proportion of $R_{\mathrm{a}}$ to $R_{\mathrm{c}}$ overlap the range of 50 to $65 \%$ reported by studies in LIS (Riley 1959), the North Atlantic (Siegel et al. 2002, Marra \& Barber 2004), and a eutrophic Danish estuary (Jensen et al. 1990). This estimate is an upper limit for the contribution of phyto- 
plankton to pelagic respiration in the water column during this study, because $R_{\mathrm{a}}$ represents not only algal respiration but also the respiration of microbial communities directly related to phytoplankton (e.g. exudates, lysis and senescence). We are not able to separate the indirect, algal-related respiratory processes that would permit a more accurate measure of actual phytoplankton respiration.

In the $P-I$ literature, algal respiration rates are commonly assumed to be a fraction of $P_{\mathrm{m}}^{B}$ for the calculation of net primary production (Riley 1946, Steemann Nielsen \& Hansen 1959, Cole \& Cloern 1984, Langdon 1993 and references therein). This appears to be based on convenience, as there is little reason to expect a relationship with a statistical physiological parameter that is independent of the level of actual productivity in situ. Previous estimates of this respiration relationship range very widely: 3 to $7 \%$ (Harris \& Piccinin 1977), $6 \%$ (Holligan et al. 1984, Jensen et al. 1990), 5 to $10 \%$ (Laws 1975), and 10\% (range of 5 to $24 \%$; Steemann Nielsen \& Hansen 1959, Cole \& Cloern 1984) of $P_{\mathrm{m}}^{B}$. This measure of respiration has also been shown to vary with species composition (range of 5 to $50 \%$ of $P_{\mathrm{m} i}^{B}$ Langdon 1993 and references therein) and day length (5 to $13 \%$ of $P_{\mathrm{m}}^{B}$ Gilstad et al. 1993). Furthermore, due to the nature of ${ }^{14} \mathrm{C}$ measurements and to authors' methodologies and assumptions, it is often unclear whether published measurements of productivity are more nearly net or gross, and occasionally it is difficult to determine whether their measurements are daytime or daily $(24 \mathrm{~h})$, or integrated or instantaneous production rates. In a regression for LIS, $R_{\mathrm{c}}$ was equivalent to $0.1 \%$ of $P_{\mathrm{m}}^{B}$ and statistically explained $\sim 8 \%$ of the variance in $P_{\mathrm{m}}^{B}$. Therefore our data do not support the use of a $\% P_{\mathrm{m}}^{B}$ as a proxy for community or algal respiration.

\section{Mid and bottom waters}

Our rates of community respiration in mid and bottom waters during periods leading to and during hypoxic conditions in LIS suggest that water column respiration is primarily responsible for the decrease in bottom water oxygen concentrations observed in LIS during summer. Measured rates of benthic respiration in the western end of LIS by Mackin et al. (1991) during the period leading up to an hypoxic event were $46.9 \mathrm{mmol} \mathrm{O}_{2} \mathrm{~m}^{-2} \mathrm{~d}^{-1}$ in early summer and $15.6 \mathrm{mmol} \mathrm{O}_{2} \mathrm{~m}^{-2} \mathrm{~d}^{-1}$ in late summer. Our summer rates of pelagic respiration near bottom averaged $20.2 \pm 19.8 \mathrm{mmol} \mathrm{O}_{2} \mathrm{~m}^{-3} \mathrm{~d}^{-1}$ (equivalent to $0.84 \pm$ $0.82 \mathrm{mmol} \mathrm{O}_{2} \mathrm{~m}^{-3} \mathrm{~h}^{-1}$ ). In a $1 \mathrm{~m}$ water layer, these values are 50 to $100 \%$ of the values of benthic metabolism reported by Mackin et al. (1991). More realistically, if we apply our seasonal ranges in pelagic respiration to a $10 \mathrm{~m}$ depth of water column, which is an underestimate of the depth of the lower portion of the water column during periods of high stratification, the average rate of pelagic respiration measurements in the lower water column during the period leading up to hypoxic events of LIS in the present study $\left(201.7 \pm 197.9 \mathrm{mmol} \mathrm{O}_{2} \mathrm{~m}^{-2} \mathrm{~d}^{-1}\right)$ is 5 to 13 times the benthic demand. This relative comparison concurs with Torgersen et al.'s (1997) estimates of the number of days it would take water column processes to deplete a $10 \mathrm{~m}$ bottom layer depth with an initial concentration of $220 \mathrm{mmol} \mathrm{O}_{2} \mathrm{~m}^{-3}$ (16 to $39 \mathrm{~d}$ ) versus that of the sediment oxygen consumption processes ( 55 to $145 \mathrm{~d}$ ) in spring and summer.

\section{CONCLUSION}

We report extensive data showing the temporal and spatial variation of $\mathrm{O}_{2}$-based measurements of $P-I$ parameters $\left(\alpha^{B}, P_{\mathrm{m}}^{B}\right)$, plankton community respiration $\left(R_{\mathrm{C}}\right)$, and phytoplankton biomass (chl). The interplay of these biological variables with environmental variables has improved our understanding of the processes primarily responsible for oxygen production and consumption in LIS. Irradiance and water column structure play major roles in the seasonal variability of biomass and $P-I$ parameters (light-adapted state) of phytoplankton. Phytoplankton biomass itself also served as an important indicator for the seasonal changes in $P_{\mathrm{m}}^{B}$. Temperature was not a good predictor for production in LIS. Since the knowledge of photosynthetic parameters $\left(P_{\mathrm{m}}^{B}\right.$ and $\left.\alpha^{B}\right)$ allows us to determine rates of specific-productivity, these results provide empirical support for the statistical use of chl, $I_{0}$ and the underwater light field as predictors for rates of gross community production in LIS.

To determine rates of net primary production, however, an estimate of algal respiration is necessary. The relationship between community respiration rates and phytoplankton biomass provides an upper limit to algal respiration, an estimate of algal-related respiration rather than algal respiration alone. Although this relationship is theoretically more robust and more rational than the previously utilized relationship estimate for algal respiration based on a percentage of $P_{\mathrm{m}}^{B}$ it is likely to overestimate algal respiration because it includes algal-related respiration of microorganisms. This algal-related respiration accounts for 43 to $60 \%$ of the daytime plankton community respiration in the surface waters of LIS. While we believe this result to be accurate, some way in which to specify algal respiration is needed, perhaps one that assumes a basal rate plus a fraction associated with specific productivity (e.g. Langdon 1993). It is not possible to parameterize such a scheme from our data or from ${ }^{14} \mathrm{C}$ measure- 
ments of photosynthesis. In any case, given an upper constraint for algal respiration, we feel more confident applying this to our direct, $\mathrm{O}_{2}$-based rates of gross community production to estimate primary productivity or rates of phytoplankton growth, than is possible with ${ }^{14} \mathrm{C}$-based rates of production.

Measurements of plankton community respiration in mid and bottom waters along the main axis of LIS exceed past measurements of sediment oxygen consumption rates in western LIS during periods leading up to and during hypoxic conditions. The magnitude and spatial distribution in these high rates of pelagic oxygen consumption of bottom waters in LIS suggest that these water column processes are likely to be more important than benthic demand in determining the gradient in the oxygen concentrations and hypoxia observed in the bottom waters of LIS.

Acknowledgements. This research was conducted with funds provided by the US EPA Office of Long Island Sound Program (awards X-98164401 and LI-97101801-0) and Connecticut Sea Grant (award NA16RG2253). Dr. Candace Oviatt provided the incubator and Matt Lyman of the CTDEP made available data from the Long Island Sound hypoxia and water quality cruises. Thanks to the crew of the RV 'Dempsey', and to Bob Degombia and Gary Grenier in the UCONN Marine Sciences machine shop. Bobby Reynolds provided capable assistance during the cruises and conducted most of the oxygen titrations.

\section{LITERATURE CITED}

Aalderink RH, Jovin R (1997) Estimation of the photosynthesis/irradiance (P/I) curve parameters from light and dark bottle experiments. J Plankton Res 19:1713-1742

Anderson TH, Taylor GT (2001) Nutrient pulses, plankton blooms, and seasonal hypoxia in western Long Island Sound. Estuaries 24:228-243

Beardall J, Morris I (1976) The concept of light intensity adaptation in marine phytoplankton: Some experiments with Phaeodactylum tricornatum. Mar Biol 37:377-388

Behrenfeld MJ, Falkowski PG (1997) Photosynthetic rates derived from satellite-based chlorophyll concentration. Limnol Oceanogr 42:1-20

Behrenfeld MJ, Prasil O, Babin M, Bruyant F (2004) In search of a physiological basis for covariations in light-limited and light-saturated photosynthesis. J Phycol 40:4-25

Bender ML, Grande K, Johnson K, Marra J and 9 others (1987) A comparison of four methods for determining planktonic community production. Limnol Oceanogr 32: 1085-1098

Brush MJ, Brawley JW, Nixon SW, Kremer JN (2002) Modeling phytoplankton production: problems with the Eppley curve and an empirical alternative. Mar Ecol Prog Ser 238: $31-45$

Cohen RRH (1990) Biochemical oxygen demand and algae: fractionation of phytoplankton and nonphytoplankton respiration in a large river. Water Resour Res 26:671-678

Cole BE, Cloern JE (1984) Significance of biomass and light availability to phytoplankton productivity in San-Francisco Bay California USA. Mar Ecol Prog Ser 17:15-24

Cote B, Platt T (1983) Day-to-day variations in the spring- summer photosynthetic parameters of coastal marine phytoplankton. Limnol Oceanogr 28:320-344

Cote B, Platt T (1984) Utility of the light-saturation curve as an operational model for quantifying the effects of environmental conditions on phytoplankton photosynthesis. Mar Ecol Prog Ser 18:57-66

Cullen JJ, Yang X, MacIntyre HL (1992) Nutrient limitation of marine photosynthesis. In: Falkowski PG, Woodhead AD (eds) Primary productivity and biogeochemical cycles in the sea. Plenum Press, New York, p 69-88

Eppley RW (1972) Temperature and phytoplankton growth in the sea. Fish Bull, (Wash DC) 70:1063-1085

Falkowski PG (1981) Light-shade adaptation and assimilation numbers. J Plankton Res 3:203-216

Figueiras FG, Perez FF, Pazos Y, Rios AF (1994) Light and productivity of Antarctic phytoplankton during austral summer in an ice edge region in the Weddell-Scotia Sea. J Plankton Res 16:233-253

Figueiras FG, Estrada M, Lopez O, Arbones B (1998) Photosynthetic parameters and primary production in the Bransfield Strait: relationships with mesoscale hydrographic structures. J Mar Syst 17:129-141

Forbes JR, Buckingham SL, Earmme AT (1987) Phytoplankton productivity experiments in British Columbia Canada coastal waters, 1986. Can Data Rep Hydrogr Ocean Sci 56

Friederich G (1991) An easy-to-construct automated Winkler titration system. MBARI Tech Rep 91-6

Gaxiola-Castro G, Alvarez-Borrego S, Lavin MF, Zirino A, Najera-Martinez S (1999) Spatial variability of the photosynthetic parameters and biomass of the Gulf of California phytoplankton. J Plankton Res 21:231-245

Gilbert M, Wilhelm C, Richter M (2000) Bio-optical modeling of oxygen evolution using in vivo fluorescence: comparison of measured and calculated photosynthesis/irradiance $(P-I)$ curves in four representative phytoplankton species. J Plant Physiol 157:307-314

Gilstad M, Johnsen G, Sakshaug E (1993) Photosynthetic parameters, pigment composition and respiration rates of the marine diatom Skeletonema costatum grown in continuous light and a 12:12 h light-dark cycle. J Plankton Res 15:939-951

Goebel NL, Kremer JN, Edwards CA (2006) Primary production in Long Island Sound. Estuar Coasts 29:232-245

Harding LW, Meeson BW, Prézelin BB, Sweeney BM (1981) Diel periodicity of photosynthesis in marine phytoplankton. Mar Biol 61:95-106

Harding LW, Prézelin B, Sweeney BM, Cox JL (1982) Primary production as influenced by diel periodicity of phytoplankton photosynthesis. Mar Biol 67:179-186

Harding LW, Meeson BW, Fisher TRJ (1985) Photosynthesis patterns in Chesapeake Bay phytoplankton: short and long-term responses of $P-I$ curve parameters to light. Mar Ecol Prog Ser 26:99-111

Harding LW, Meeson BW, Fisher TRJ (1986) Phytoplankton production in two east coast estuaries photosynthesis-light functions and patterns of carbon assimilation in Chesapeake and Delaware Bays USA. Estuar Coast Shelf Sci 23: 773-806

Harding LW, Mallonee ME, Perry ES (2002) Toward a predictive understanding of primary productivity in a temperate, partially stratified estuary. Estuar Coast Shelf Sci 55: 437-463

Harris GP, Piccinin BB (1977) Photosynthesis by natural phytoplankton populations. Arch Hydrobiol 80:405-457

Holligan PM, Williams PJLeB, Purdie D, Harris RP (1984) Photosynthesis, respiration and nitrogen supply of plank- 
ton populations in stratified, frontal and tidally mixed shelf waters. Mar Ecol Prog Ser 17:201-213

Hopkinson CS, Smith EM (2005) Estuarine respiration: an overview of benthic, pelagic, and whole system respiration. In: del Giorgio PA, Williams PJL (eds) Respiration in aquatic ecosystems. Oxford University Press, Oxford, p 122-146

Ichimura S (1960) Photosynthetic pattern of natural phytoplankton relating to light intensity. Bot Mag Tokyo 73:458-467

Jassby AD, Platt T (1976) Mathematical formulation of the relationship between photosynthesis and light for phytoplankton. Limnol Oceanogr 21:540-547

Jensen LM, Sand Jensen K, Marcher S, Hansen M (1990) Plankton community respiration along a nutrient gradient in a shallow Danish estuary. Mar Ecol Prog Ser 61:75-85

Kelly JR, Doering PH (1997) Monitoring and modeling primary production in coastal waters: studies in Massachusetts Bay 1992-1994. Mar Ecol Prog Ser 148:155-168

Kirk JTO (1994) Light and photosynthesis in aquatic ecosystems, 2nd edn. Press Syndicate of the University of Cambridge, Cambridge

Kremer JN, Nixon SW (1978) A coastal marine ecosystem: simulation and analysis. Springer-Verlag, Heidelberg

Langdon C (1993) The significance of respiration in production measurements based on oxygen. ICES Mar Sci Symp 197:69-78

Laws EA (1975) The importance of respiration losses in controlling the size distribution of marine phytoplankton. Ecology 56:419-427

Laws EA (1991) Photosynthetic quotients, new production and net community production in the open ocean. DeepSea Res 38:143-167

Lohrenz S, Cullen JJ, Phinney DA, Olson DB, Yentsch C (1993) Distributions of pigments and primary production in a Gulf Stream meander. J Geophys Res 98:14545-14560

MacCaull WA, Platt T (1977) Diel variations in the photosynthetic parameters of coastal marine phytoplankton. Limnol Oceanogr 22:723-731

Macedo MF, Duarte P, Mendes P, Ferreira JG (2001) Annual variation of environmental variables, phytoplankton species composition and photosynthetic parameters in a coastal lagoon. J Plankton Res 23:719-732

Mackin J, Aller R, Vigil H, Rude P (1991) Nutrient and dissolved oxygen fluxes across the sediment-water interface, in Long Island Sound study: Final Report, Sediment geochemistry and biology, US-EPA Contract CE 002870026. Section IV, p 1-252

Malone TC, Neale PJ (1981) Parameters of light-dependent photosynthesis for phytoplankton size fractions in temperate estuarine and coastal environments. Mar Biol 61: 289-297

Marra J, Barber RT (2004) Phytoplankton and heterotrophic respiration in the surface layer of the ocean. Geophys Res Lett 31:L09314

Oviatt CA, Rudnick DT, Keller AA, Sampou PA, Almquist GT (1986) Patterns of productivity during eutrophication: a mesocosm experiment. Mar Ecol Prog Ser 28:69-80

Oviatt CA, Keller AA, Reed L (2002) Annual primary production in Narragansett Bay with no bay-wide winterspring phytoplankton bloom. Estuar Coast Shelf Sci 54: 1013-1026

Parsons TR, Maita Y, Lalli CM (1984) A manual of chemical and biological methods for seawater analysis. Pergamon Press, Oxford

Editorial responsibility: Yves Collos (Contributing Editor), Montpellier, France
Platt T, Jassby AD (1976) The relationship between photosynthesis and light for natural assemblages of coastal marine phytoplankton. J Phycol 12:421-430

Platt T, Sathyedranath S (1993) Estimators of primary production for the interpretation of remotely sensed data of ocean color. J Geophys Res 98:14561-14576

Platt T, Gallegos CL, Harrison GW (1980) Photoinhibition of photosynthesis in natural assemblages of marine phytoplankton. J Mar Res 38:687-701

Prézelin BB, Matlick HA (1980) Time-course of photoadaptation in the photosynthesis-irradiance relationship of a dinoflagellate exhibiting photosynthetic periodicity. Mar Biol 58:85-96

Prézelin BB, Sweeney BM (1977) Characterization of photosynthetic rhythm in marine dinoflagellates. 2. photosynthesis-irradiance curves and in vivo chlorophyll a fluorescence. Plant Physiol 60:388-392

Press WH, Flannery BP, Teukolsky SA, Vetterling WT (1992) Numerical recipes: the art of scientific computing. Cambridge University Press, Cambridge

Riley GA (1946) Factors controlling phytoplankton population on Georges Bank. J Mar Res 6:54-73

Riley GA (1959) Oceanography of Long Island Sound, 1954-1955. Bull Bingham Oceanogr Collect Yale Univ 17: 9-29

Robinson C, Williams PJL (2005) Respiration and its measurement in surface marine waters. In: del Giorgio PA, Williams PJL (eds) Respiration in aquatic ecosystems. Oxford University Press, Oxford, p 147-180

Sakshaug E, Bricaud A, Dandonneau Y, Falkowski PG and 5 others (1997) Parameters of photosynthesis: definitions, theory and interpretation of results. J Plankton Res 19: $1637-1670$

Siegel DA, Doney SC, Yoder JA (2002) The North Atlantic spring phytoplankton bloom and Sverdrup's critical depth hypothesis. Science 296:730-733

Sosik HM, Mitchell BG (1995) Light absorption by phytoplankton, photosynthetic pigments and detritus in the California Current System. Deep-Sea Res I 42: $1717-1748$

Steemann Nielsen E, Hansen VK (1959) Light adaptation in marine phytoplankton populations and its interrelationships with temperature. Physiol Plant 12:353-370

Torgersen T, Deangelo E, O'Donnell J (1997) Calculations of horizontal mixing rates using ${ }^{222} \mathrm{Rn}$ and the controls on hypoxia in western Long Island Sound 1991. Estuaries 20: 328-345

Turekian KK, Tanaka N, Turekian VC, Torgersen T, DeAngelo EC (1996) Transfer rates of dissolved tracers through estuaries based on ${ }^{228} \mathrm{Ra}$ : a study in Long Island Sound. Cont Shelf Res 16:863-873

van Belle G (2002) Statistical rules of thumb. John Wiley \& Sons, New York

Walsby AE (1997) Numerical integration of phytoplankton photosynthesis through time and depth in a water column. New Phytol 136:189-209

Webb WL, Newton M, Starr D (1974) Carbon dioxide exchange of Alnus rubra: a mathematical model. Ecologia 17:281-291

Welsh BL, Eller FC (1991) Mechanisms controlling summertime oxygen depletion in western Long Island Sound. Estuaries 14:265-278

Wong KC (1990) Sea level variability in Long Island Sound. Estuaries 13:362-372

Submitted: October 7; 2005 Accepted: February 9, 2006

Proofs received from author(s): November 27, 2006 